\title{
Apical progenitors remain multipotent throughout cortical neurogenesis
}

\author{
Polina Oberst $^{1}$, Sabine Fièvre ${ }^{1}$, Natalia Baumann ${ }^{1}$, Cristina Concetti ${ }^{1} \uparrow \&$ Denis Jabaudon ${ }^{1,2}$
}

\author{
${ }^{1}$ Department of Basic Neurosciences, University of Geneva, 1211 Geneva, Switzerland. \\ ${ }^{2}$ Clinic of Neurology, Geneva University Hospital, 1211 Geneva, Switzerland. \\ $\dagger$ Present address: Institute of Neuroscience, ETH Zürich, 8603 Schwerzenbach, Switzerland. \\ Correspondence to: denis.jabaudon@unige.ch
}

The diverse subtypes of excitatory neurons that populate the neocortex are born from progenitors located in the ventricular zone (apical progenitors, APs). During corticogenesis, APs progress through successive temporal states to sequentially generate deep- followed by superficial-layer neurons directly or via the generation of intermediate progenitors (IPs). Yet little is known about the plasticity of AP temporal identity and whether individual progenitor subtypes remain multipotent throughout corticogenesis. To address this question, we used FlashTag (FT), a method to pulse-label and isolate APs in the mouse neocortex with high temporal resolution to fate-map neuronal progeny following heterochronic transplantation of APs into younger embryos. We find that unlike daughter IPs, which lose the ability to generate deep layer neurons when transplanted into a younger host, APs are temporally uncommitted and become molecularly respecified to generate normally earlier-born neuron types. These results indicate that APs are multipotent cells that are able to revert their temporal identity and re-enter past molecular and neurogenic states. AP fate progression thus occurs without detectable fate restriction during the neurogenic period of corticogenesis. These findings identify unforeseen celltype specific differences in cortical progenitor fate plasticity, which could be exploited for neuroregenerative purposes.

During neocorticogenesis, distinct subtypes of neurons are sequentially generated, and can be distinguished by their laminar location, connectivity, and gene expression programs (Greig et al., 2013; Jabaudon, 2017). They are born from dynamic subtypes of progenitors (i.e. apical and intermediate progenitors) whose molecular identities and neurogenic potential are increasingly understood (Gaspard et al., 2008; Gao et al., 2014; Okamoto et al., 2016; Yuzwa et al., 2017; Mihalas and Hevner, 2018), but whose corresponding fate potential remains unknown. While the aggregate ability of cortical progenitor populations to generate earlier-born neuron types when transplanted in a younger host appears to be lost (Frantz and McConnell, 1996; Desai and McConnell, 2000), whether individual subtypes of progenitors have the potential to revert to previous temporal states remains unexamined. Here, we take advantage of a recently developed method to isolate specific populations of cortical progenitor cells (Telley et al., 2016; Govindan et al., 2018) and probe their fate potential using heterochronic transplantation into younger hosts.

In order to interrogate the temporal plasticity of AP identity, we performed FlashTag (FT) pulse-labeling in CAG::mRFP1 donor mice and immediately isolated FT-labeled cells using flow cytometry (FT specifically labels APs based on their juxtaventricular location) (Telley et al., 2016; Govindan et al., 2018). These $\mathrm{FT}^{+}$APs were transplanted into wild-type (WT) host embryos by intraventricular injection (Nagashima et al., 2014) (Fig. 1, Fig. S1a), and the fate of their $\left(\mathrm{RFP}^{+}\right)$neuronal progeny was determined on postnatal day $(\mathrm{P}) 7$, once migration is complete. To unequivocally identify neurons born in the host, we chronically administered EdU to the host dam from the time 
of transplantation on (Farah, 2004), such that host-born transplanted neurons could be identified as $\mathrm{RFP}^{+} \mathrm{EdU}^{+}$cells. We first performed isochronic AP transplantations at E15.5 $\left(\mathrm{AP}_{15 \rightarrow 15}\right)$, a time at which superficial layer (SL) neurons (i.e. neurons in layers (L) 4 and $2 / 3)$ are born, and at $\mathrm{E} 12.5\left(\mathrm{AP}_{12 \rightarrow 12}\right)$, a time at which deep-layer (DL) neurons (i.e. L6 and L5) are generated (Greig et al., 2013; Jabaudon, 2017). Using these two conditions as controls, we then heterochronically transplanted E15.5 APs into E12.5 host embryos ( $\left.\mathrm{AP}_{15 \rightarrow 12}\right)$.

Integration of donor APs into the host ventricular zone (VZ) occurred at discrete sites (typically 5-6 integration sites per host embryo, with an average of 2 donor APs per integration site, Fig. S1b). Within 24 hours, donor cells in the VZ had a typical radial glia morphology, including a radial process extending to the pial surface and juxtaventricular mitosis (Florio and Huttner, 2014; Govindan and Jabaudon, 2017) (Fig. S1c). Over the course of several days, the progeny of transplanted APs migrated away from the VZ, following a time course that was similar to that of endogenous cells (Fig. S1d). When examined at $\mathrm{P} 7$, both $\mathrm{AP}_{15 \rightarrow 15}$ and $\mathrm{AP}_{12 \rightarrow 12}$ had generated daughter neurons with appropriate laminar locations: $\mathrm{AP}_{15 \rightarrow 15}$ gave rise to $\mathrm{SL}$ neurons (Fig. 1b, Fig. S2, Supplementary Table 1) while $\mathrm{AP}_{12 \rightarrow 12}$ gave rise to $\mathrm{DL}$ and $\mathrm{SL}$ neurons, consistent with the sequential production of DL followed by SL neurons (Fig. 1c, Fig. S3, Supplementary Table 1). At each integration site, about 8 neurons were found at P7; these numbers are consistent with these cells being the progeny of mostly 1-2 progenitors (Gao et al., 2014), i.e. "oligoclones", as reported above (Fig. S1b and Methods). The laminar distribution of daughter neurons in both the $\mathrm{AP}_{15 \rightarrow 15}$ and $\mathrm{AP}_{12 \rightarrow 12}$ conditions was replicated by in utero electroporation of a piggyBactransposon construct (which allows fate mapping by genomic integration of a fluorescent proteincoding transgene into progenitors (Chen and LoTurco, 2012)), indicating that the transplantation procedure itself does not detectably affect AP neurogenic competence (Fig. S4, Supplementary Table 1).

In striking contrast to the normally exclusive SL location of $\mathrm{AP}_{15 \rightarrow 15}$ daughter neurons, in the $\mathrm{AP}_{15 \rightarrow 12}$ condition, daughter neurons were located in both DL and SL, as described above
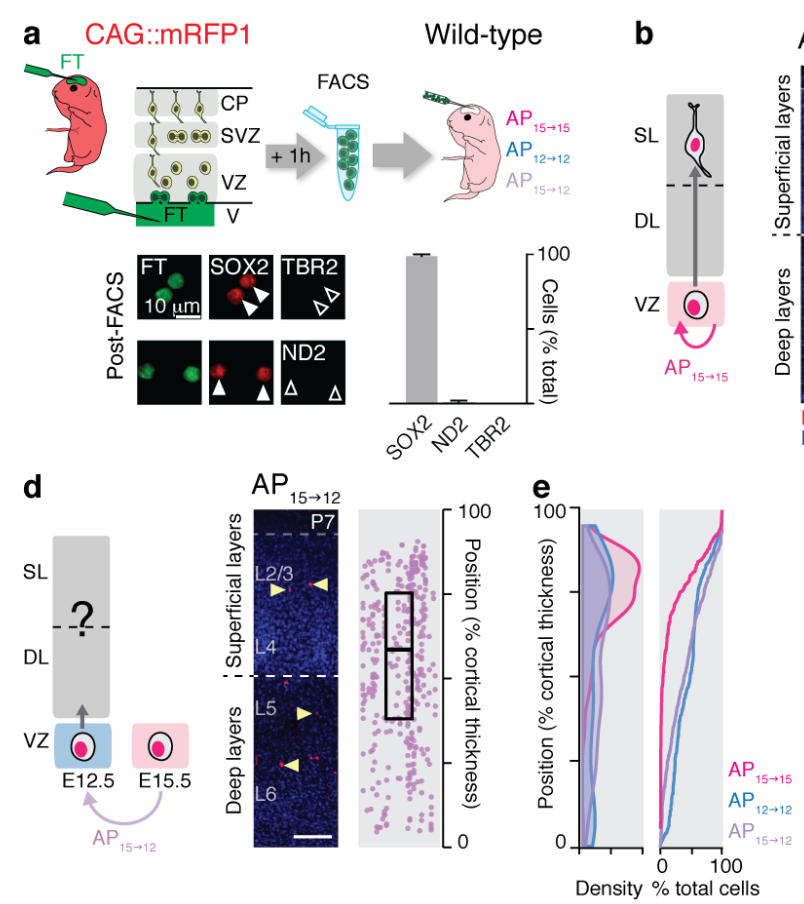
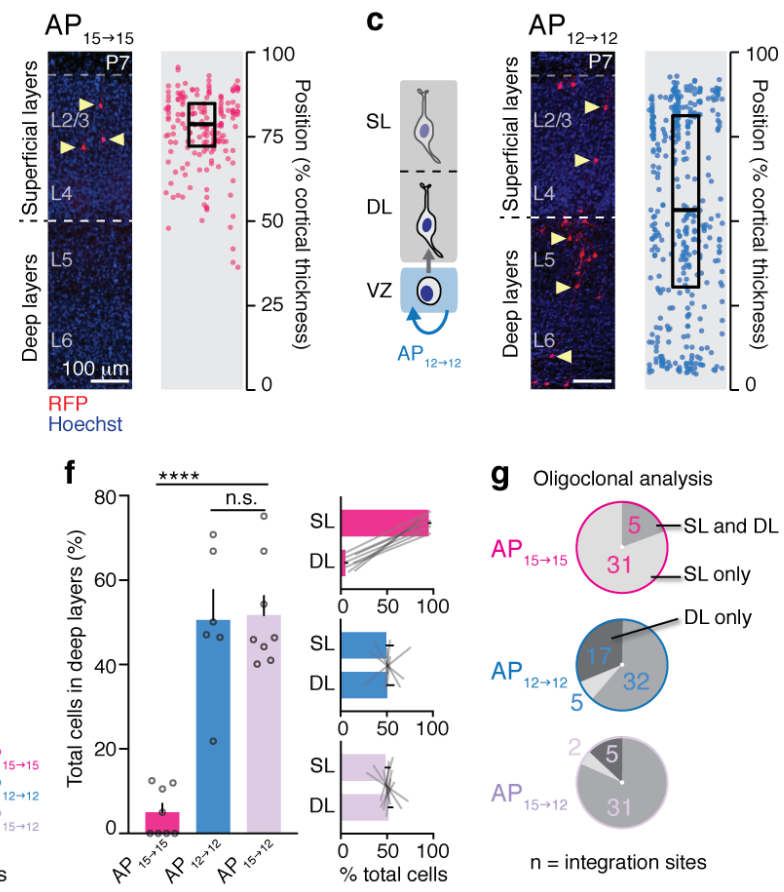

Figure 1: E15.5 apical progenitors (APs) remain competent to generate earlier-born deep layer neurons. a, Top: Schematic representation of the AP isolation and transplantation procedure. Bottom: Donor cells consist essentially of SOX2 ${ }^{+}$APs. TBR2: IP marker; ND2 (NeuroD2): neuronal marker. b, Isochronically transplanted E15.5 APs $\left(\mathrm{AP}_{15 \rightarrow 15}\right)$ generate superficial layer (SL) neurons. c, Isochronically transplanted E12.5 APs $\left(\mathrm{AP}_{12 \rightarrow 12}\right)$ give rise to deep layer (DL) and SL neurons. d, E15.5 APs transplanted into an E12.5 host $\left(\mathrm{AP}_{15 \rightarrow 12}\right)$ give rise to $\mathrm{DL}$ and SL neurons. e, Radial distribution of daughter neurons at $\mathrm{P} 7 . \mathbf{f}$, Left: Fraction of daughter neurons in deep layers at P7. One-way ANOVA with post-hoc Tukey test. Right: Modal distribution of daughter neurons in SL vs. DL. g, Oligoclonal integration site analysis of the laminar distribution of daughter neurons (see also Fig. S1b). CP: cortical plate; FT: FlashTag; SVZ: subventricular zone; V: Ventricle; VZ: ventricular zone. $* * * *$ : P $<0.0001$. b-d: on right panels, vertically-aligned cells belong to single integration sites. 
for $\mathrm{AP}_{12 \rightarrow 12}$ (Fig. 1d-f, Fig. S5a, b, Supplementary Table 1). This laminar redistribution was also present when examining individual oligoclonal integration sites (Fig. 1g). This consistent laminar redistribution across all integration sites argues against a populationbased effect in which only few transplanted cells are highly plastic, but instead suggests that essentially all integrated APs are undergoing respecification. Together, these data suggest that E15.5 APs remain competent to generate DL neurons.

DL neurons in the $\mathrm{AP}_{15 \rightarrow 12}$ condition could in principle reflect a mismigration of this fraction of cells, which nonetheless retain SL molecular identities. To investigate this possibility, we
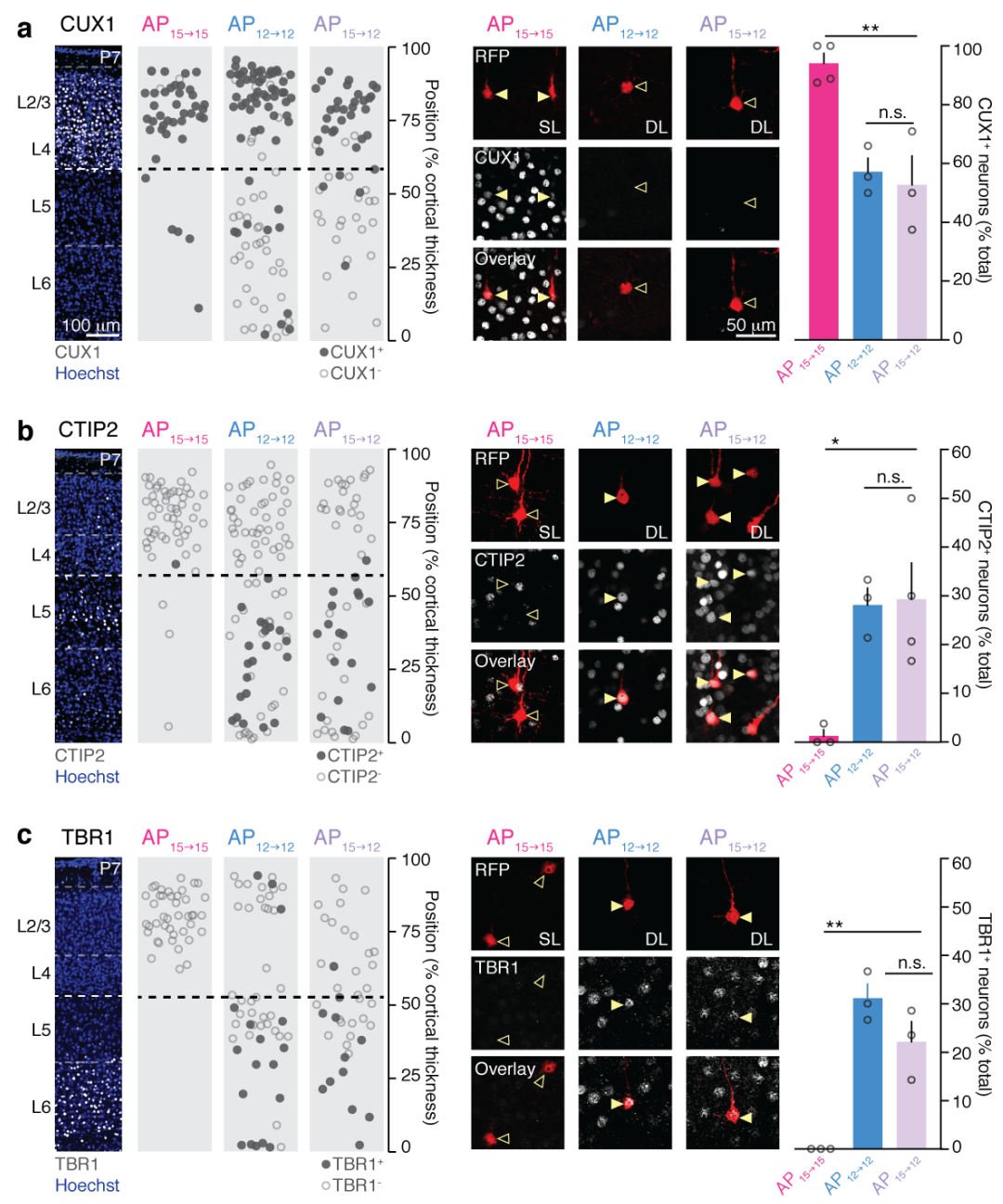

$$
\text { d }
$$
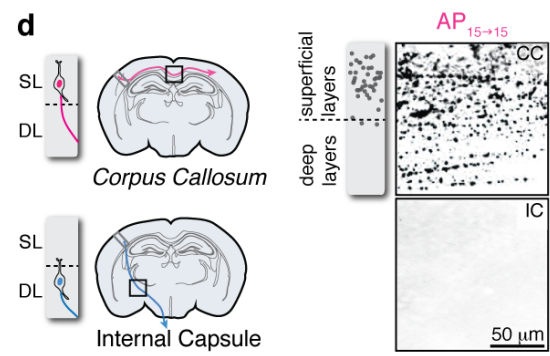
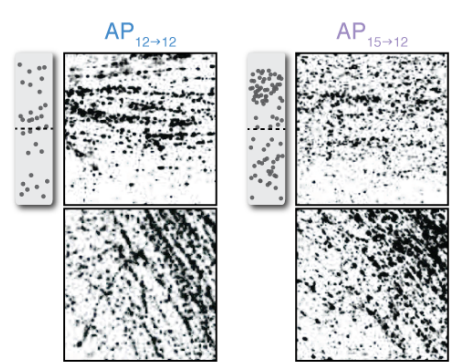

examined the molecular identity and axonal projections of daughter neurons (Fig. 2). Molecular identity was assessed using TBR1, a marker of L6 neurons, CTIP2, a marker of L5 neurons, and CUX1, a marker of L2-4 neurons (Greig et al., 2013). Expression of these molecular markers in $\mathrm{AP}_{15 \rightarrow 12}$ daughter neurons was congruent with laminar position: CUX1 was expressed by SL neurons while CTIP2 and TBR1 were expressed by DL neurons (Fig. 2a-c, Fig. S6a-c). This harmonious laminar and molecular identity strongly suggest a respecification of the $\mathrm{AP}_{15 \rightarrow 12}$ progeny. Further supporting this possibility, in contrast to the neuronal progeny of E15.5 APs, which send axons to intracortical but not to subcerebral targets (Greig et al., 2013), the $\mathrm{AP}_{15 \rightarrow 12}$ progeny also projected subcerebrally, as do E12.5 AP daughter neurons (Fig. 2d). Together, these data reveal an embryonic ageappropriate and congruous respecification of the laminar, molecular, and hodological identity of $\mathrm{AP}_{15 \rightarrow 12}$ daughter neurons.

DL neuronal identity could in principle result from a postmitotic process rather than from a pre-mitotic respecification of $\mathrm{AP}_{15 \rightarrow 12}$. To investigate this possibility, we examined the fate of the small population of neurons which were being born in the donor

Figure 2: Embryonic ageappropriate molecular features and connectivity of $\mathbf{A P}_{\mathbf{1 5} \rightarrow \mathbf{1 2}}$ daughter neurons. a, CUX1, a superficial layer (SL) neuron marker, is reduced in deep layer (DL) $\mathrm{AP}_{15 \rightarrow 12}$ daughter neurons. b, CTIP2, a DL neuron marker, is increased in $\mathrm{DL} \mathrm{AP}_{15 \rightarrow 12}$ daughter neurons. c, TBR1, a DL neuron marker, is increased in $\mathrm{DL} \mathrm{AP}_{15 \rightarrow 12}$ daughter neurons. a-c: one-way ANOVA with post-hoc Tukey test. d, $\mathrm{AP}_{15 \rightarrow 12}$ daughter neurons extend subcerebral projections via the internal capsule. Photomicrographs show $\mathrm{RFP}^{+}$axons from the same pup for each condition. Insets on their left show the laminar position of neurons in the corresponding pup. CC: Corpus Callosum; IC: Internal Capsule. *: $\mathrm{P}<0.05, * *$ : $\mathrm{P}$ $<0.01$. 
at the time of isolation. In contrast to $\mathrm{AP}_{15 \rightarrow 12}$, these neurons, identified as $\mathrm{RFP}^{+} \mathrm{EdU}^{-}$cells (i.e. transplanted cells which never underwent division in the host) still migrated to SL, as they would have done in their original host, indicating that they were already committed to an SL fate (Fig. S6d,e). Thus, emergence of DL neurons in the $\mathrm{AP}_{15 \rightarrow 12}$ condition appears to result from a pre-mitotic rather than a post-mitotic process.

Do $\mathrm{AP}_{15}$ acquire an $\mathrm{AP}_{12}$ identity upon heterochronic transplantation? To directly identify potential changes in the molecular identity of $\mathrm{AP}_{15 \rightarrow 12}$, we performed patch-seq RNA sequencing (Cadwell et al., 2016; Fuzik et al., 2016) of visually-identified $\mathrm{RFP}^{+}$ juxtaventricular cells (i.e. presumptive APs) (Fig. 3a). We first determined the embryonic age-specific transcriptional identity of normal $\mathrm{AP}_{15}$ and $\mathrm{AP}_{12}$ and compared $\mathrm{AP}_{15 \rightarrow 12}$ identity to these two control conditions using a linear regression model (Teo et al., 2010). Similarly, we generated an additional model to specifically identify genes distinguishing $\mathrm{AP}_{15 \rightarrow 12}$ from normal $\mathrm{AP}_{15}$ (i.e. to identify genes whose expression changes upon heterochronic transplantation of $\mathrm{AP}_{15}$ ) (Fig. 3b,c, Fig. S7). This two-pronged approach revealed that $\mathrm{AP}_{15 \rightarrow 12}$ repress $\mathrm{AP}_{15}$-type transcriptional programs and re-induce $\mathrm{AP}_{12}$-type transcriptional programs, and identified dynamically regulated genes following heterochronic transplantation (Fig. 3b,c, Fig. S7). Re-induced, normally earlyexpressed genes included the Wnt pathway regulator Tcf7ll, which represses neuronal differentiation and increases self-renewal in cortical apical progenitors (Kuwahara et al., 2014) and polycomb repressive complex 2 (PRC2) methyltransferase Ezh2, in the absence of which APs undergo precocious neurogenesis (Pereira et al., 2010). Both of these genes thus act on the dynamically regulated balance between self-renewal and differentiation during corticogenesis (Paridaen and Huttner, 2014). Repressed, normally late-onset, genes included Tenascin c (Tnc), an extracellular glycoprotein involved in the onset of gliogenesis late in corticogenesis (Garcion et al., 2004) and Mfge8, coding for an EGF-like domain containing protein, which regulates quiescence in adult neural stem cells (Zhou et al., 2018). Together, these results reveal that the temporal shift in the neurogenic competence of $\mathrm{AP}_{15 \rightarrow 12}$ is accompanied by a corresponding wholesale shift in their global molecular identity. a
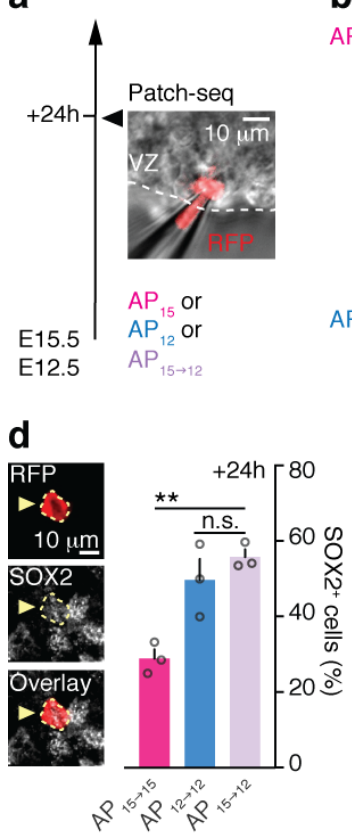

b
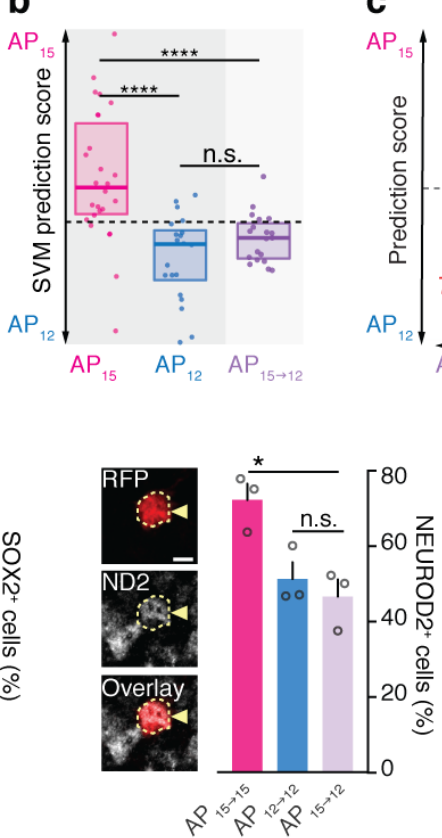
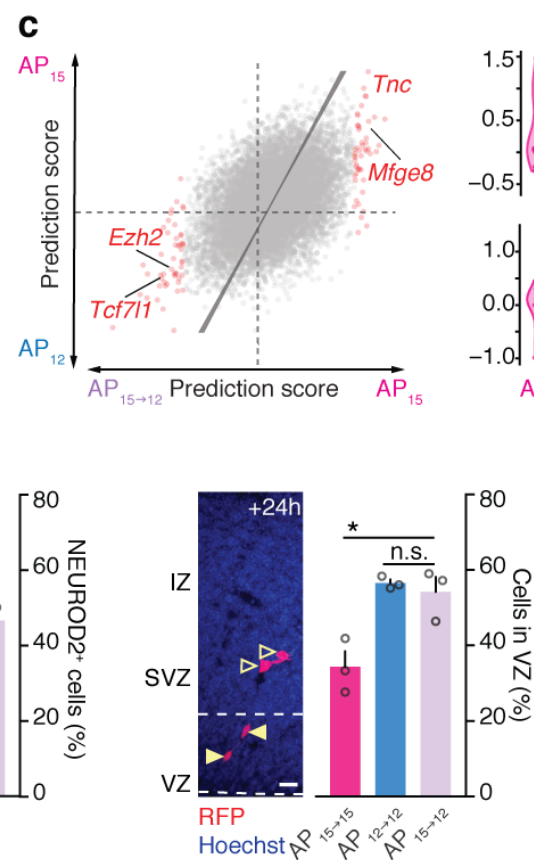
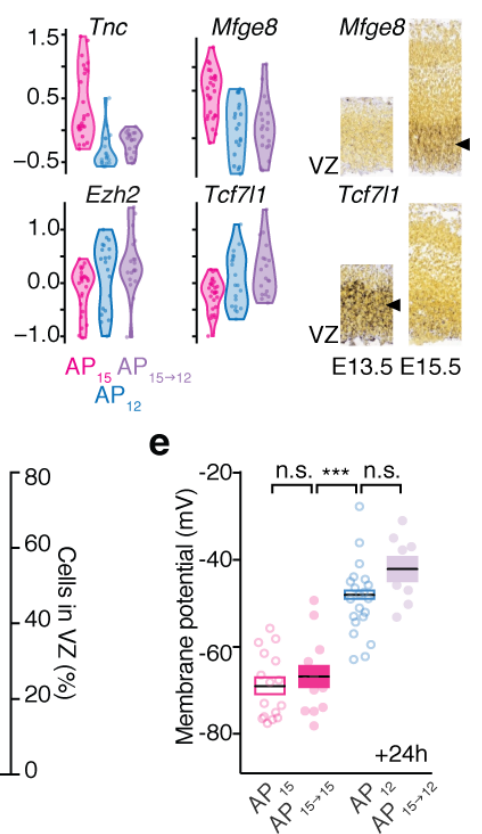

Figure 3: $\mathbf{A} \mathbf{P}_{15}$ are respecified into $\mathbf{A} \mathbf{P}_{12}$ upon transplantation. a, Summary of the experimental approach used for patch-seq single cell RNA sequencing. Inset: patched AP. b, SVM classification reveals that $\mathrm{AP}_{15 \rightarrow 12}$ acquire an $\mathrm{AP}_{12}$-type molecular identity. Kolmogorov-Smirnov test. c, $\mathrm{AP}_{15 \rightarrow 12}$ repress $\mathrm{AP}_{15}$ - and induce $\mathrm{AP}_{12}$-enriched transcripts. Right: examples of $\mathrm{AP}_{15}$ and $\mathrm{AP}_{12}$ genes that are repressed or induced in $\mathrm{AP}_{15 \rightarrow 12}$. Insets: in situ hybridizations from the Allen Developing Mouse Brain Atlas confirm transcriptomic data (www.brain-map.org). d, Neurogenic divisions decrease to $\mathrm{AP}_{12}$ values in $\mathrm{AP}_{15 \rightarrow 12}$. Accordingly, more cells remain in the VZ. One-way ANOVA with post-hoc Tukey-test. e, The membrane potential of $\mathrm{AP}_{15 \rightarrow 12}$ depolarizes to $\mathrm{AP}_{12}$ values. Kruskal-Wallis test with post-hoc Dunn's test. IZ: intermediate zone; ND2 (NeuroD2): neuronal marker; SOX2: AP marker; SVM: support vector machine; SVZ: subventricular zone; VZ: ventricular zone. One-way ANOVA with post-hoc Tukey test. *: $\mathrm{P}<0.05, * *$ : $\mathrm{P}<0.01, * * *$ : $\mathrm{P}<0.001, * * * *$ : $\mathrm{P}<0.0001$. 
We next examined whether this E12-like molecular re-specification of $\mathrm{AP}_{15 \rightarrow 12}$ was accompanied by a corresponding reassignment of their functional features (Fig. 3d,e). For this purpose, we measured two key temporallyregulated physiological parameters of these cells:

(1) Neurogenic divisions. Symmetric divisions predominate early in corticogenesis while asymmetric, neuron-generating divisions increase at later embryonic stages (Haubensak et al., 2004; Govindan and Jabaudon, 2017). Accordingly, $\mathrm{RFP}^{+} \mathrm{SOX}^{+}$cells (i.e. cycling transplanted APs) were more prevalent in the $\mathrm{AP}_{12 \rightarrow 12}$ condition than the $\mathrm{AP}_{15 \rightarrow 15}$ condition (Fig. 3d, left), while the reverse was true for RFP $^{+} \mathrm{NEUROD}^{+}$cells (i.e. daughter neurons) (Fig. 3d, center). Similarly, in line with a higher self-replication rate of APs early in corticogenesis, a greater fraction of daughter cells remained in the $\mathrm{VZ}$ in the $\mathrm{AP}_{12 \rightarrow 12}$ condition (Fig. 3d, right). Consistent with acquisition of $\mathrm{AP}_{12}$-like mitotic properties by $\mathrm{AP}_{15 \rightarrow 12}, \mathrm{SOX}^{+}$daughter cells increased, NEUROD2 ${ }^{+}$daughter cells decreased, and daughter cells remained in the VZ, as was the case for $\mathrm{AP}_{12 \rightarrow 12}$ (Fig. 3d).

(2) Resting membrane potential. Progression of AP neurogenic competence is regulated by a progressive hyperpolarization of the resting membrane potential $\left(\mathrm{V}_{\mathrm{m}}\right)$ in a Wnt-dependent manner (Vitali et al., 2018). Since the Wnt pathway regulator Tcf7ll was re-induced in $\mathrm{AP}_{15 \rightarrow 12}$ (Fig. 3c), we hypothesized that a resetting of $V_{m}$ values might contribute to the respecification process. To examine this possibility, we measured $\mathrm{V}_{\mathrm{m}}$ values in transplanted APs using whole-cell patch clamp recording. $\mathrm{V}_{\mathrm{m}}$ values in isochronicallytransplanted cells did not differ from their host counterparts, indicating that this electrophysiological parameter is not affected by the transplantation procedure. In contrast, $\mathrm{AP}_{15 \rightarrow 12} \mathrm{~V}_{\mathrm{m}}$ values were reset to those of APs in their E12.5 host, revealing a reassignment of this critical regulator of AP competence, potentially contributing to neurogenic re-specification (Fig. $3 e)$.

Together, the results above reveal a reset in the molecular and physiological properties of $\mathrm{AP}_{15 \rightarrow 12}$, which are reassigned to those of their younger host.
Our results contrast with earlier findings in which progenitor cells transplanted into younger hosts could no longer generate DL neurons (Frantz and McConnell, 1996; Desai and McConnell, 2000). In these seminal experiments, progenitors were identified by incorporation of radiolabeled thymidine, which labels S-phase cells across the VZ, subventricular zone and outer subventricular zone (Angevine and Sidman, 1961). Late in corticogenesis, and particularly in the ferret (the species in which these experiments were performed), the majority of progenitors are IPs (Reillo and Borrell, 2012). In these studies, the fate plasticity identified here may thus have been occluded by the overwhelming predominance of other, potentially less plastic, progenitor cell types, and particularly by IPs. In addition, in contrast to APs, which divide multiple times, IPs are thought to divide only once or twice before reaching a terminal division (Mihalas et al., 2016; Mihalas and Hevner, 2018). As a consequence, radiolabeled thymidine, which was used in these early studies, will be more diluted in the neuronal progeny of APs than in the progeny of IPs, potentially biasing quantifications towards the latter lineage.

To investigate the possibility of cell-type specific differences in progenitor plasticity, we first reproduced the strategy used to isolate progenitors in these earlier experiments: following microdissection and dissociation of the dorsal pallium at E15.5, we used the thymidine analog EdU to single pulse-label VZ and SVZ progenitors and identify their progeny in the host (Fig. 4a). Following transplantation into E12.5 hosts, daughter neurons, identified as $\mathrm{EdU}^{+}$cells, were mostly located in SL, replicating earlier findings in the ferret (Fig. 4b, Fig. S8, Supplementary Table 1). Thus, compared with previous studies, our new results reflect cell-type specific rather than speciesspecific features of progenitor plasticity, and suggest that the competence for progenitor respecification is subtype dependent.

In light of these results, we hypothesized that while E15.5 APs are temporally plastic, E15.5 daughter IPs instead are committed to generating SL neurons. To test this possibility, we performed FT labeling at E15.5 and waited 10 hours before collection to allow daughter IPs to differentiate (Telley et al., 2016; Govindan et al., 2018). At this stage, $>75 \%$ of $\mathrm{FT}^{+}$cells have differentiated into IPs, as revealed by co- 
expression of TBR2 and the proliferation marker KI67 (Vitali et al., 2018) (Fig. 4c, Fig. S9a). Upon examination of single integration sites at P7, transplanted IPs gave rise to a smaller number of cells than APs, consistent with a more differentiated status and a limited number of divisions (Gao et al., 2014; Mihalas et al., 2016; Mihalas and Hevner, 2018) (Fig. S9b). In contrast to $\mathrm{AP}_{15 \rightarrow 12}, \mathrm{IP}_{15 \rightarrow 12}$ essentially gave rise to SL neurons (Fig. 4d-f, Fig. S9c, Supplementary Table 1). Consistent with their location, these neurons expressed CUX1 but not CTIP2 (Fig. S9d). Similarly, as predicted by the lack of temporal plasticity of newborn neurons (Fig. S6e) 10 hour-old E15.5 neurons (identified as $\mathrm{RFP}^{+} \mathrm{EdU}^{-}$cells, i.e. transplanted cells which never underwent division in the chronic EdUperfused host, see Fig. S6d) did not change their fate when transplanted into E12.5 hosts (Fig. S9e). These results demonstrate that in contrast to their mother cells, differentiated IPs are committed progenitors with a fixed neurogenic competence.

Together, our findings reveal an outstanding ability of APs to revert their temporal identity and re-enter past molecular states to once again generate normally earlier-born neurons. In contrast, IPs are committed progenitors which lack such fate plasticity. These results highlight an unexpected cell-type specific diversity in the temporal plasticity of neocortical progenitors. Moreover, they reveal that AP fate progression occurs without detectable fate restriction during the neurogenic period of corticogenesis. Thus, although the arc of development in whole organisms inescapably extends towards maturity, subsets of cells can be untethered from this course and remain able to re-enter past developmental states.

While technical limitations had so far precluded access to the cell-type specific temporal plasticity identified here, the ability of progenitor cells to at least partially revert to earlier embryonic states has been described in other settings. For example, in Drosophila neuroblasts, late re-expression of early temporal identity factors leads to the production of previously generated cells (Cleary and Doe, 2006; Kohwi and Doe, 2013; Kohwi et al., 2013). Similarly, re-expression of the earlyneuron transcription factor $F e z f 2$ at later corticogenic stages leads to re-emergence of neurons with deep-layer identities (Molyneaux et al., 2005), and inactivation of the transcription factor Foxgl late in development leads to resurgence of early-born Cajal-Retzius neurons (Hanashima, 2004). Together with classical cell biology work showing that nuclear transfer from adult somatic cells into enucleated oocytes leads to nuclear reprogramming to younger states (Gurdon, 1962; Wakayama et al., 1998), these examples indicate that the transcriptional programs used during development remain amenable to re-recruitment even after progenitor fate has progressed.

The temporal resetting in $\mathrm{V}_{\mathrm{m}}$ values identified here may contribute to the reassignment in AP identity and regulate sensitivity to extracellular signals (Vitali et al., 2018). Such temporally dynamic environmental factors may include cellcell interactions (Mutch et al., 2009; Okamoto et al., 2016), metabolic supplies, neurotransmitter-
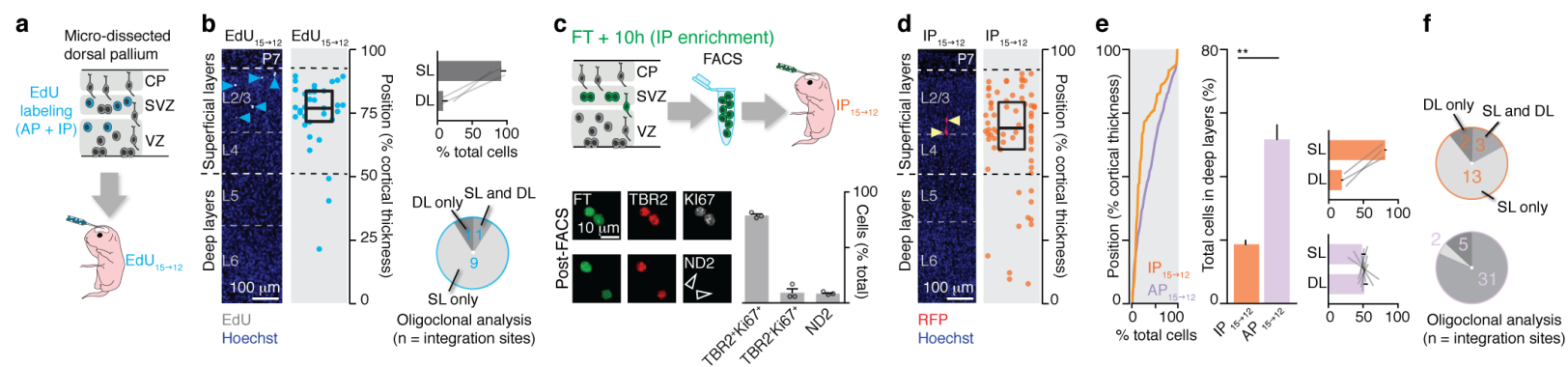

Figure 4: E15.5 intermediate progenitors (IPs) are committed to generating superficial layer neurons. a, Left: Schematic representation showing transplantation of EdU-based labeling and transplantation procedure. b, E15.5 EdU ${ }^{+}$cells transplanted into an E12.5 host $\left(\mathrm{EdU}_{15 \rightarrow 12}\right)$ still give rise to SL neurons. Compare with Fig. 1d. Right, top: Modal distribution of daughter neurons in SL vs. DL. Right, bottom: Single integration site analysis of the laminar distribution of daughter neurons. ce, Schematic representation of the IP isolation and transplantation procedure. d, E15.5 IPs transplanted into an E12.5 host $\left(\mathrm{IP}_{15 \rightarrow 12}\right)$ essentially give rise to SL neurons. e, Left: Radial distribution of the daughter neurons of $\mathrm{IP}_{15 \rightarrow 12}$ and $\mathrm{AP}_{15 \rightarrow 12}$ at $\mathrm{P} 7$. Center: Fraction of daughter neurons in DL at P7. Student's t-test. Right: Modal distribution of daughter neurons in SL vs. DL in the $\mathrm{IP}_{15 \rightarrow 12}$ condition and $\mathrm{AP}_{15 \rightarrow 12}$ condition. $\mathbf{f}$, Oligoclonal integration site analysis of the laminar distribution of daughter neurons. $\mathrm{AP}_{15 \rightarrow 12}$ data in e-f have been reproduced from Fig. 1 e-g for direct comparison with $\mathrm{IP}_{15 \rightarrow 12}$. CP: cortical plate; FT: FlashTag; ND2 (NeuroD2): neuronal marker; SVZ: subventricular zone; TBR2: IP marker; V: Ventricle; VZ: ventricular zone. b,d: Vertically-aligned cells belong to single integration sites. 
mediated feedback from newborn neurons or nearby axons (Seuntjens et al., 2009; Toma et al., 2014), as well as the protein and ion composition of the neurogenic niche and cerebrospinal fluid (Lehtinen et al., 2011), which together may be involved in AP re-specification. It will be important, in future studies, to understand the precise sequence of extrinsic and intrinsic, permissive and instructive events underlying such a remarkable level of plasticity, and attempt to harness these processes for neuroregenerative purposes.

\section{Acknowledgements}

We thank Eiman Azim and members of the Jabaudon lab for comments on the manuscript. We thank Olivier Raineteau for providing plasmids. We thank Andrea S. Lopes, Audrey Benoit, the FACS facility, the Genomics Platform and the Bioimaging Facility of the University of Geneva for technical assistance. Work in the Jabaudon laboratory is supported by the Swiss National Science Foundation. P.O. is supported by the iGE3.

\section{Author Contributions}

P.O. performed the experiments with the help of C.C.; S.F. performed the electrophysiology experiments and the collection of cells for patch-seq with the help of P.O.; N.B. performed the bioinformatic analysis; P.O. and D.J. wrote the manuscript.

\section{Competing interests}

None.

\section{Data and material availability}

Annotated data and accession numbers will be available upon manuscript publication. The supplementary materials contain additional data.

\section{References}

Angevine, J.B., and Sidman, R.L. (1961). Autoradiographic study of cell migration during histogenesis of cerebral cortex in the mouse. Nature 192, 766-768.

Cadwell, C.R., Palasantza, A., Jiang, X., Berens, P., Deng, Q., Yilmaz, M., Reimer, J., Shen, S.,
Bethge, M., Tolias, K.F., et al. (2016). Electrophysiological, transcriptomic and morphologic profiling of single neurons using Patch-seq. Nat. Biotechnol. 34, 199-203.

Chen, F., and LoTurco, J. (2012). A method for stable transgenesis of radial glia lineage in rat neocortex by piggyBac mediated transposition. J. Neurosci. Methods 207, 172-180.

Cleary, M.D., and Doe, C.Q. (2006). Regulation of neuroblast competence: multiple temporal identity factors specify distinct neuronal fates within a single early competence window. Genes Dev. 20, 429-434.

Desai, A.R., and McConnell, S.K. (2000). Progressive restriction in fate potential by neural progenitors during cerebral cortical development. Development 127, 2863-2872.

Farah, M.H. (2004). Cumulative labeling of embryonic mouse neural retina with bromodeoxyuridine supplied by an osmotic minipump. J. Neurosci. Methods 134, 169-178.

Florio, M., and Huttner, W.B. (2014). Neural progenitors, neurogenesis and the evolution of the neocortex. Development 141, 2182-2194.

Frantz, G.D., and McConnell, S.K. (1996). Restriction of Late Cerebral Cortical Progenitors to an Upper-Layer Fate. Neuron 17, 55-61.

Fuzik, J., Zeisel, A., Máté, Z., Calvigioni, D., Yanagawa, Y., Szabó, G., Linnarsson, S., and Harkany, T. (2016). Integration of electrophysiological recordings with single-cell RNA-seq data identifies neuronal subtypes. Nat. Biotechnol. 34, 175-183.

Gao, P., Postiglione, M.P., Krieger, T.G., Hernandez, L., Wang, C., Han, Z., Streicher, C., Papusheva, E., Insolera, R., Chugh, K., et al. (2014). Deterministic Progenitor Behavior and Unitary Production of Neurons in the Neocortex. Cell 159, 775-788.

Garcion, E., Halilagic, A., Faissner, A., and ffrench-Constant, C. (2004). Generation of an environmental niche for neural stem cell development by the extracellular matrix molecule tenascin C. Development 131, 34233432 .

Gaspard, N., Bouschet, T., Hourez, R., Dimidschstein, J., Naeije, G., van den Ameele, J., Espuny-Camacho, I., Herpoel, A., Passante, L., Schiffmann, S.N., Gaillard, A., and 
Vanderhaeghen, P. (2008). An intrinsic mechanism of corticogenesis from embryonic stem cells. Nature 7211, 351-7.

Govindan, S., and Jabaudon, D. (2017). Coupling progenitor and neuronal diversity in the developing neocortex. FEBS Lett. 591, 3960-3977.

Govindan, S., Oberst, P., and Jabaudon, D. (2018). In vivo pulse-labeling of isochronic cohorts of cells in the central nervous system using FlashTag. Nat. Protoc. 13, 2297-2311.

Greig, L.C., Woodworth, M.B., Galazo, M.J., Padmanabhan H., and Macklis, J.D. (2013).

Molecular logic of neocortical projection neuron specification, development and diversity. Nat.

Rev. Neurosci. 11, 755-69.

Gurdon, J.B. (1962). The developmental capacity of nuclei taken from intestinal epithelium cells of feeding tadpoles. J. Embryol. Exp. Morphol. 10, 622-640.

Hanashima, C., Li, S.C., Shen, L., Lai, E., and Fishell, G. (2004). Foxg1 Suppresses Early Cortical Cell Fate. Science 303, 56-59.

Haubensak, W., Attardo, A., Denk, W., and Huttner, W.B. (2004). Neurons arise in the basal neuroepithelium of the early mammalian telencephalon: a major site of neurogenesis. Proc. Natl. Acad. Sci. U. S. A. 101, 3196-3201.

Jabaudon, D. (2017). Fate and freedom in developing neocortical circuits. Nat. Commun. 8,16042 .

Kohwi, M., and Doe, C.Q. (2013). Temporal fate specification and neural progenitor competence during development. Nat. Rev. Neurosci. 14, 823-838.

Kohwi, M., Lupton, J.R., Lai, S.-L., Miller, M.R., and Doe, C.Q. (2013). Developmentally Regulated Subnuclear Genome Reorganization Restricts Neural Progenitor Competence in Drosophila. Cell 152, 97-108.

Kuwahara, A., Sakai, H., Xu, Y., Itoh, Y., Hirabayashi, Y., and Gotoh, Y. (2014). Tcf3 Represses Wnt- $\beta$-Catenin Signaling and Maintains Neural Stem Cell Population during Neocortical Development. PLoS ONE 9, e94408.

Lehtinen, M.K., Zappaterra, M.W., Chen, X., Yang, Y.J., Hill, A.D., Lun, M., Maynard, T., Gonzalez, D., Kim, S., Ye, P., et al. (2011). The cerebrospinal fluid provides a proliferative niche for neural progenitor cells. Neuron 69, 893-905.

Long, J.Z., Lackan, C.S., and Hadjantonakis, A.K. (2005). Genetic and spectrally distinct in vivo imaging: embryonic stem cells and mice with widespread expression of a monomeric red fluorescent protein. BMC Biotechnol. 5, 20.

Mihalas, A.B., and Hevner, R.F. (2018). Clonal analysis reveals laminar fate multipotency and daughter cell apoptosis of mouse cortical intermediate progenitors. Development 145, $\operatorname{dev} 164335$.

Mihalas, A.B., Elsen, G.E., Bedogni, F., Daza, R.A.M., Ramos-Laguna, K.A., Arnold, S.J., and Hevner, R.F. (2016). Intermediate Progenitor Cohorts Differentially Generate Cortical Layers and Require Tbr2 for Timely Acquisition of Neuronal Subtype Identity. Cell Rep. 16, 92105.

Molyneaux, B.J., Arlotta, P., Hirata, T., Hibi, M., and Macklis, J.D. (2005). Fezl Is Required for the Birth and Specification of Corticospinal Motor Neurons. Neuron 47, 817-831.

Mutch, C.A., Funatsu, N., Monuki, E.S., and Chenn, A. (2009). Beta-Catenin Signaling Levels in Progenitors Influence the Laminar Cell Fates of Projection Neurons. J. Neurosci. 29, 13710-13719.

Nagashima, F., Suzuki, I.K., Shitamukai, A., Sakaguchi, H., Iwashita, M., Kobayashi, T., Tone, S., Toida, K., Vanderhaeghen, P., and Kosodo, Y. (2014). Novel and Robust Transplantation Reveals the Acquisition of Polarized Processes by Cortical Cells Derived from Mouse and Human Pluripotent Stem Cells. Stem Cells Dev. 23, 2129-2142.

Okamoto, M., Miyata, T., Konno, D., Ueda, H.R., Kasukawa, T., Hashimoto, M., Matsuzaki, F., and Kawaguchi, A. (2016). Cell-cycleindependent transitions in temporal identity of mammalian neural progenitor cells. Nat. Commun. 7, 11349.

Paridaen, J.T., and Huttner, W.B. (2014). Neurogenesis during development of the vertebrate central nervous system. EMBO Rep. 15, 351-364.

Pereira, J.D., Sansom, S.N., Smith, J., Dobenecker, M.-W., Tarakhovsky, A., and Livesey, F.J. (2010). Ezh2, the histone 
Livesey, F.J. (2010). Ezh2, the histone methyltransferase of $\mathrm{PRC} 2$, regulates the balance between self-renewal and differentiation in the cerebral cortex. Proc. Natl. Acad. Sci. 107, 15957-15962.

Reillo, I., and Borrell, V. (2012). Germinal Zones in the Developing Cerebral Cortex of Ferret: Ontogeny, Cell Cycle Kinetics, and Diversity of Progenitors. Cereb. Cortex 22, 2039-2054.

Seuntjens, E., Nityanandam, A., Miquelajauregui, A., Debruyn, J., Stryjewska, A., Goebbels, S., Nave, K.A., Huylebroeck, D., and Tarabykin, V. (2009). Sip1 regulates sequential fate decisions by feedback signaling from postmitotic neurons to progenitors. Nat. Neurosci. 12, 1373-1380.

Telley, L., Govindan, S., Prados, J., Stevant, I., Nef, S., Dermitzakis, E., Dayer, A., and Jabaudon, D. (2016). Sequential transcriptional waves direct the differentiation of newborn neurons in the mouse neocortex. Science 351, 1443-1446.

Teo, C.H., Vishwanathan, S.V.N., and Smola, A. (2010). Bundle Methods for Regularized Risk Minimization. J. Mach. Learn. Res. 11, 311-365.

Toma, K., Kumamoto, T., and Hanashima, C. (2014). The timing of upper-layer neurogenesis is conferred by sequential derepression and negative feedback from deep-layer neurons. J. Neurosci. 34, 13259-13276.

Vitali, I., Fièvre, S., Telley, L., Oberst, P., Bariselli, S., Frangeul, L., Baumann, N., McMahon, J.J., Klingler, E., Bocchi, R., et al. (2018). Progenitor Hyperpolarization Regulates the Sequential Generation of Neuronal Subtypes in the Developing Neocortex. Cell 174, 12641276.e15.

Wakayama, T., Perry, A.C., Zuccotti, M., Johnson, K.R., and Yanagimachi, R. (1998). Full-term development of mice from enucleated oocytes injected with cumulus cell nuclei. Nature 394, 369-374.

Yuzwa, S.A., Borrett, M.J., Innes, B.T., Voronova, A., Ketela, T., Kaplan, D.R., Bader, G.D., and Miller, F.D. (2017). Developmental Emergence of Adult Neural Stem Cells as Revealed by Single-Cell Transcriptional Profiling. Cell Rep. 21, 3970-3986.
Zhou, Y., Bond, A.M., Shade, J.E., Zhu, Y., Davis, C.O., Wang, X., Su, Y., Yoon, K.-J., Phan, A.T., Chen, W.J., et al. (2018). Autocrine Mfge8 Signaling Prevents Developmental Exhaustion of the Adult Neural Stem Cell Pool. Cell Stem Cell 23, 444-452.e4. 


\title{
Methods
}

\begin{abstract}
Mice
Experiments were performed using CD1 (Charles River) and CAG::mRFP1 (B6.Cg-Tg(CAGmRFP1)1F1Hadj/J, JAX 005884) (Long et al., 2005) mice. CAG::mRFP1 mice were bred on a CD1 background for at least 10 generations before use. Embryonic day (E) 0.5 was established as the day of vaginal plug. Both female and male embryos were used throughout the study. All experimental procedures were approved by the Geneva Cantonal Veterinary Authorities, Switzerland.
\end{abstract}

\section{In utero Flash Tag labeling}

FT injections were performed at E12.5 and E15.5 as previously described (Govindan et al., 2018; Telley et al., 2016). Briefly, pregnant mice were anaesthetized with isoflurane and an abdominal incision was made to access the uterine horns. Half a microliter of $10 \mathrm{mM}$ carboxyfluorescein succinimidyl ester ("FlashTag"; CellTraceTM CFSE, Life Technologies, \#C34554) was injected into the lateral ventricles of embryos using a picospritzer. The abdominal wall was sutured and the embryos let to develop until collection.

\section{Preparation of cell suspension and in utero cell transplantation}

One hour after FT labeling (unless otherwise stated) E12.5 or E15.5 donor embryos were collected in ice-cold HBSS and the dorsal pallium was microdissected under stereomicroscopic guidance (Leica, \#M165 FC) using a microscalpel. Tissue from 6-8 littermates was pooled and incubated in $400 \mu 1$ TrypLE (Gibco, \#12605-010) for 3 minutes at $37{ }^{\circ} \mathrm{C}$. TrypLE was inactivated by adding HBSS containing $0.1 \%$ BSA and the tissue was mechanically dissociated by triturating with a $1 \mathrm{ml}$ pipette. Cells were filtered through a $70 \mu \mathrm{m}$ cell strainer, centrifuged $(150 \mathrm{rpm}, 5$ minutes) and resuspended in FACS buffer (L15 medium containing $2 \mathrm{mg} / \mathrm{ml}$ glucose, 0.1\% BSA, 1:50 citrate phosphate dextrose, 10 units/ml DNase I and $1 \mu \mathrm{M} \mathrm{MgCl}_{2}$ ). Cells were sorted on an S3e Cell Sorter (BioRad) or a BD FACS Aria II flow cytometer (BD Biosciences) and the top $5-10 \%$ brightest cells (Govindan et al., 2018; Telley et al., 2016), were collected in ice-cold FACS buffer. Sorted cells were centrifuged (150 rpm, 5 minutes) and resuspended in HBSS containing $10 \mathrm{mM}$ EGTA (Nagashima et al., 2014) and $0.1 \%$ fast green to a final density of 25,000-75,000 cells per $\mu$ l. Cells were kept on ice until the start of the transplantation procedure. Five hundred $\mu 1$ of the cell suspension (corresponding to approximately $12,500-37,500$ cells) was injected into the lateral ventricles of each host embryo using a picospritzer.

\section{Continuous EdU labeling}

A $10 \mathrm{mg} / \mathrm{ml} \mathrm{EdU} \mathrm{solution} \mathrm{was} \mathrm{prepared} \mathrm{in} \mathrm{(1:1)} \mathrm{DMSO:water.} \mathrm{An} \mathrm{osmotic} \mathrm{pump} \mathrm{(Alzet,} \mathrm{\# 1003D)}$ was filled with the solution and pre-incubated at $37^{\circ} \mathrm{C}$ for $4-12$ hours. The pump was placed in the peritoneal cavity of the mother at the end of the surgical procedure to allow for continuous administration of EdU. If continuous delivery was required for more than 3 days (i.e. when started at E12.5), a new pump prepared in the same way as above was introduced after 72 hours. Revelation of EdU was performed using Click-it chemistry following the manufacturer's instructions (Invitrogen).

\section{Oligoclonal analysis}

Integration sites were defined as sites containing transplanted cells that are separated from other transplanted cells by at least $500 \mu \mathrm{m}$ in either direction. Cells within each integration site correspond to progeny of a few integrated cells (see Fig. S1b). 


\title{
In utero electroporation
}

In utero electroporations were performed as previously described (Vitali et al., 2018). Briefly, a 1.5 $\mu \mathrm{g} / \mu \mathrm{l}$ DNA solution containing 1:2 transposon pPB-CAG-EmGFP and hyperactive piggyBac transposase (pRP-Puro-CAGG-Pbase) (Chen and LoTurco, 2012) was prepared in sterile PBS containing $0.01 \mathrm{mg} / \mathrm{mL}$ fast green. Half a microliter of DNA solution was injected unilaterally into the lateral ventricle of embryos using a picospritzer and electroporation was performed by applying 5 electric pulses (25 V for E12.5, $45 \mathrm{~V}$ for E15.5; $50 \mathrm{~ms}$ at $1 \mathrm{~Hz}$ ) with a square-wave electroporator (Nepa Gene, Sonidel Limited, UK). Embryos were let to develop until collection at P7.

\section{Immunohistochemistry}

Embryonic brains were collected in PBS and fixed in 4\% paraformaldehyde (PFA) overnight at $4^{\circ} \mathrm{C}$. Postnatal mice were perfused with $4 \%$ PFA and brains were post-fixed in $4 \%$ PFA overnight at $4{ }^{\circ} \mathrm{C}$. Fifty to $100 \mu \mathrm{m}$ coronal sections were cut using a vibrating microtome (Leica, \#VT100S). Antigenretrieval was performed by incubating the sections in citrate buffer solution (Dako, \#S1699) for 20 minutes at $82^{\circ} \mathrm{C}$. Sections were rinsed three times in PBS and incubated overnight at $4{ }^{\circ} \mathrm{C}$ with primary antibodies diluted in PBS containing 3\% BSA and 0.3\% Triton-X-100. Sections were rinsed three times in PBS containing 0.1\% Tween 20 and incubated for 1 hour at room temperature with corresponding secondary antibodies (1:500, Life Technologies). Sections were washed twice with PBST and incubated with Hoechst for 5 minutes (1:5000 in PBS, Life Technologies, \#33342) to stain nuclei. Sections were dry mounted on slides using Fluoromount (Sigma, \# F4680).

\section{Immunocytochemistry of FAC-sorted cells}

Sorted cells were resuspended in FACS buffer at a density of 25,000 cells per ml, seeded on glass coverslips coated with poly-d-lysine and laminin and maintained at $37{ }^{\circ} \mathrm{C}$ with $5 \% \mathrm{CO}_{2}$ for 30 minutes to allow cells to adhere to the coverslips. Cells were fixed with 4\% PFA (15 min at RT), rinsed three times with PBS and permeabilized by incubation with $0.25 \%$ Triton-X-100 in PBS for 10 minutes, followed by three washes in PBS. Blocking was performed with $1 \%$ BSA in PBST for 1 hour, followed by incubation with primary antibodies for 2 hours at room temperature. Cells were rinsed three times in PBS and incubated for 1 hour at room temperature with corresponding secondary antibodies (1:500, Life Technologies). Sections were washed two times with PBS and incubated with Hoechst for 5 minutes (1:5000 in PBS) to stain nuclei. Coverslips were mounted on slides using Fluoromount.

\begin{abstract}
Antibodies
Rat anti-CTIP2 (1:500; Abcam, \#AB18465); rabbit anti-CUX1 (1:500; Santa Cruz; sc-13024); rabbit anti-dsRed (1:1000; Clonetech; \# 632496); rabbit anti-KI67 (1:250; Abcam, \#AB15580); rabbit antiNEUROD2 (1:1000; Abcam, \#AB104430); rat anti-RFP (1:500; Chromotek; \# 5F8); goat anti-SOX2 (1:500; SC Biotech, \#SC17320); mouse anti-SOX2 (1:500; Santa Cruz; sc-365823); rabbit anti-TBR1 (1:500; Abcam; \# AB31940); rabbit anti-TBR2 (1:500; Abcam; ab23345); rat anti-TBR2 (1:500; Invitrogen, \#14-4875-82).
\end{abstract}

\section{Image acquisition, quantification and statistical analyses}

Images were acquired using an Eclipse 90i epifluorescence microscope (Nikon), a LSM 700 line scan confocal (Carl Zeiss) or a Nikon A1r spectral line scan confocal (Nikon) and analyzed with ImageJ software. For analysis of transplantations, brains from each recipient litter (i.e. containing cells from one independent FACS experiment/one donor litter) were pooled for analysis and considered as one replicate ("N"), except when indicated otherwise. Only neurons located in the neocortex were included in analysis, and glia were excluded based on morphology. All results are shown as mean \pm 
SEM, except when indicated otherwise. The following convention was used: *: $P<0.05, * *: P<$ $0.01, * * *: P<0.001, * * * *: P<0.0001$.

Figure 1a and 4c: Three to four coverslips $(=\mathrm{N})$ from 2 independent FACS experiments were analyzed for each condition. Figure 1a: 73 cells were stained for SOX2 and ND2 (\% SOX2 ${ }^{+}: 98.91 \pm$ $1.09 ; \%$ ND2 $\left.2^{+}: 1.09 \pm 1.09\right) ; 50$ cells were stained for TBR2 (\% TBR2 $\left.{ }^{+}: 0\right)$. Figure 4c: 121 cells were stained for TBR2 and Ki67 (\% TBR2 ${ }^{+} \mathrm{Ki}^{+} 7^{+}: 78.84 \pm 1.41$; \% TBR2- Ki67 ${ }^{+}: 9.21 \pm 3.37$ ); 214 cells were stained for ND2 (\% ND2 $\left.{ }^{+}: 8.4 \pm 0.75\right)$.

Figure 1b-g: Cells from all transplantation experiments collected at $\mathrm{P} 7$ were included in analysis. $\mathrm{AP}_{15 \rightarrow 15}: 238$ cells from 8 independent experiments $(=\mathrm{N})$ and 36 integration sites; $\mathrm{AP}_{12 \rightarrow 12}: 385$ cells from 6 independent experiments and 54 integration sites; $\mathrm{AP}_{15 \rightarrow 12}$ : 381 cells from 8 independent experiments and 38 integration sites. Figures $1 \mathrm{~b}-\mathrm{d}$ : The radial position of cells within the neocortex was measured and normalized to the cortical thickness. The normalized radial position for each cell was plotted and cells were aligned on the X-axis per integration site. Chronic EdU labeling was used to identify transplanted host-born neurons in all experiments, except donor litters: $\mathrm{AP}_{15 \rightarrow 15} 1,2,7,8$; $\mathrm{AP}_{12 \rightarrow 12} 2,3,5 ; \mathrm{AP}_{15 \rightarrow 12} 1,3,4,5$. Figure 1e: Density and cumulative distribution plots were used to additionally display the radial positions of cells. Figure 1f: Left: The percentage of total cells in DL per donor litter is plotted $\left(\mathrm{AP}_{15 \rightarrow 15}: 5.0 \pm 2.05\right.$; $\mathrm{AP}_{12 \rightarrow 12}: 50.4 \pm 7.11$; $\left.\mathrm{AP}_{15 \rightarrow 12}: 51.62 \pm 4.53\right)$. A oneway ANOVA with post-hoc Tukey test was used. Right: The percentage of total cells in DL and SL per donor litter is plotted. SL DL values from the same experiment are connected with lines. Figure 1g: Individual integration sites were examined for each condition and the number of oligoclones containing cells in only SL, only DL or both SL and DL were plotted.

Figure 2: A subset of cells depicted in Fig. 1 was analyzed for molecular marker expression. The normalized radial position of labeled and non-labeled cells and the total percentage of cells expressing the respective marker were plotted. $\mathrm{AP}_{15 \rightarrow 15}: 42$ cells from 4 independent experiments were stained for CUX1 (\% CUX1 $\left.{ }^{+}: 94.1 \pm 3.42\right) ; 54$ cells from 3 independent experiments were stained for CTIP2 (\% CTIP2 $\left.{ }^{+}: 1.28 \pm 1.28\right)$; 48 cells from 3 independent experiments were stained for TBR1 (\% TBR $1^{+}$: $0) . \mathrm{AP}_{12 \rightarrow 12}: 102$ cells from 3 independent experiments were stained for CUX1 (\% CUX1 ${ }^{+}: 57.19 \pm$ 4.69); 53 cells from 3 independent experiments were stained for CTIP2 (\% CTIP2 $\left.{ }^{+}: 28.13 \pm 3.52\right) ; 55$ cells from 3 independent experiments were stained for TBR1 ( $\%$ TBR $\left.1^{+}: 31.11 \pm 2.94\right)$. AP $15 \rightarrow 12: 59$ cells from 3 independent experiments were stained for CUX1 (\% CUX1 $\left.{ }^{+}: 52.82 \pm 9.76\right) ; 81$ cells from 4 independent experiments were stained for CTIP2 $\left(\% \mathrm{CTIP}^{+}: 29.34 \pm 7.43\right) ; 38$ cells from 3 independent experiments were stained for TBR1 $\left(\%\right.$ TBR $\left.1^{+}: 22.13 \pm 4.18\right)$. A one-way ANOVA with post-hoc Tukey test was used.

Figure 3b: A Kolmogorov-Smirnov test was used. AP 12 : 20 cells, $\mathrm{AP}_{15}: 26$ cells, $\mathrm{AP}_{15 \rightarrow 12}: 29$ cells: 19 cells.

Figure 3d: Left: $\mathrm{AP}_{15 \rightarrow 15}: 56$ cells from 3 independent experiments $(=\mathrm{N})$ were stained for SOX2 (\% $\left.\mathrm{SOX}^{+}: 28.97 \pm 2.41\right) ; 54$ cells from 3 independent experiments were stained for ND2 (\% ND2 ${ }^{+}$: $72.59 \pm 3.88) . \mathrm{AP}_{12 \rightarrow 12}$ : 49 cells from 3 independent experiments were stained for SOX2 (\% SOX2 ${ }^{+}$: $49.75 \pm 5.57) ; 72$ cells from 3 independent experiments were stained for ND2 (\% ND2 $2^{+}: 51.24 \pm$ 4.38). $\mathrm{AP}_{15 \rightarrow 12}: 134$ cells from 3 independent experiments were stained for $\mathrm{SOX} 2\left(\% \mathrm{SOX}^{+}: 55.83 \pm\right.$ 1.97); 63 cells from 3 independent experiments were stained for ND2 (\% ND2 $\left.{ }^{+}: 46.56 \pm 4.57\right)$. Right: For analysis of cells remaining in the VZ $24 \mathrm{~h}$ after transplantation, cells from 3 independent experiments $(=\mathrm{N})$, including a subset of cells used for SOX2/ND2 expression analysis shown in Fig. $3 \mathrm{~d}$, were analyzed. $\mathrm{AP}_{15 \rightarrow 15}: 120$ cells total (\% cells in VZ: $\left.34.28 \pm 4.13\right)$. $\mathrm{AP}_{12 \rightarrow 12}: 66$ cells total (\% cells in VZ: $56.6 \pm 0.95)$. $\mathrm{AP}_{15 \rightarrow 12}: 134$ cells total (\% cells in VZ: $\left.54.15 \pm 3.94\right)$. A one-way ANOVA with post-hoc Dunnett test was used.

Figure 3e: The resting membrane potential of transplanted or non-transplanted FT labeled control cells was recorded 24 hours after transplantation or FT labeling. Recordings from at least 3 independent experiments per condition were pooled for analysis. $\mathrm{AP}_{15}:-69.01 \pm 1.89 \mathrm{mV} ; \mathrm{N}=16$ cells. $\mathrm{AP}_{15 \rightarrow 15}:-66.8 \pm 2.58 \mathrm{mV} ; 12$ cells. $\mathrm{AP}_{12}:-48.96 \pm 1.82 \mathrm{mV} ; 21$ cells. $\mathrm{AP}_{15 \rightarrow 12}:-42.08 \pm 2.82$ $\mathrm{mV} ; 8$ cells. A Kruskal-Wallis test with a post-hoc Dunn's test was used. 
Figure 4b: 34 cells from 3 independent experiments $(=N)$ and 11 integration sites were analyzed. Left: The normalized radial position of EdU ${ }^{+}$cells was plotted and cells were aligned on the $\mathrm{X}$-axis per integration site. Right, top: The layer position for each cell was plotted. SL and DL values from the same experiment are connected with lines. Right, bottom: Individual integration sites were examined and the number of oligoclones containing cells in only SL, only DL or both SL and DL were plotted.

Figure 4d-f: 81 cells from 3 independent experiments $(=\mathrm{N})$ and 18 integration sites were analyzed. For comparison, $\mathrm{AP}_{15 \rightarrow 12}$ data reproduced from Fig. 1f are shown. Figure 4d: The normalized radial position of $\mathrm{RFP}^{+} \mathrm{EdU}^{+}$cells was plotted and cells were aligned on the X-axis per integration site. Figure 4e: Left: Density and cumulative distribution plots were used to additionally display the radial positions of cells. Center: The percentage of total cells in DL per donor litter is plotted (IP ${ }_{15 \rightarrow 12}: 18.98$ $\pm 1.27)$. A student's t-test was used. Right: The percentage of total cells in DL and SL per donor litter is plotted. SL and DL values from the same experiment are connected with lines. Figure 4f: Individual integration sites were examined for each condition and the number of oligoclones containing cells in only SL, only DL or both SL and DL were plotted.

Figure S1a: The number of integrated cells per integration site was analyzed 6 hours after transplantation of $\mathrm{AP}_{15 \rightarrow 15}$. A total of 93 cells from 3 independent experiments $(=\mathrm{N})$, corresponding to 43 integration sites, were analyzed. Number of cells per integration site: 1-6; mean: 2.16; median: 2.

Figure S1c: Brains were collected at consecutive time-points after $\mathrm{AP}_{15 \rightarrow 15}$ transplantation or E15.5 FT labeling. The distance of cells to the lateral ventricle was measured using ImageJ. RFP: 6h: 46 cells, $14.89 \pm 1.99 \mu \mathrm{m}$; $12 \mathrm{~h}: 21$ cells, $29.54 \pm 7.35 ; 24 \mathrm{~h}: 30$ cells, $68.95 \pm 13.25 ; 48 \mathrm{~h}: 30$ cells, 259.4 \pm 26.85 ; 72h: $636.2 \pm 63.42$. FT: $6 \mathrm{~h}: 36$ cells, $35.29 \pm 3.78$; $12 \mathrm{~h}: 25$ cells, $69.9 \pm 5.27 ; 24 \mathrm{~h}: 92.79 \pm$ 8.36; 48h: 39 cells, $225.3 \pm 23.97$; $72 \mathrm{~h}: 681.2 \pm 36.43$.

Figures S2, S3, S5a, S8, S9c, S9e bottom: Images from all cells used for analysis are shown for each condition. In the plots, the normalized radial position is shown. Cells are aligned on the X-axis per integration site. Figures S2, S3, S5: Chronic EdU labeling was used to identify transplanted host-born neurons in all experiments, except: $\mathrm{AP}_{15 \rightarrow 15}$ : donor litters 1, 2, 7, 8; $\mathrm{AP}_{12 \rightarrow 12}$ : donor litters 2, 3, 5; $\mathrm{AP}_{15 \rightarrow 12}$ : donor litters 1, 3, 4, 5. Figure S8: only $\mathrm{EdU}^{+}$cells were included in analysis. Figure S9c: Only $\mathrm{EdU}^{+} \mathrm{RFP}^{+}$neurons were included in analysis. Figure S9e, bottom: Only EdU $\mathrm{RFP}^{+}$neurons were included in analysis.

Figure S4: The radial position of $\mathrm{GFP}^{+}$neurons within the neocortex was normalized to the cortical thickness. At least 3 pups $(=\mathrm{N})$, and 3 sections from different rostro-caudal levels per pup, were used per condition. The layer position for each cell was plotted. In cortical areas with no anatomically distinguishable L4, the lowest $1 / 3$ of $\mathrm{L} 2 / 3$ was considered as L4. Cells in $\mathrm{L} 2 / 3(\%): \mathrm{PB}_{15}: 92.13 \pm 1$; $\mathrm{PB}_{12}: 38.83 \pm 1.28$. Cells in L4 (\%): $\mathrm{PB}_{15}: 7.39 \pm 0.66$; $\mathrm{PB}_{12}: 13.67 \pm 1.24$. Cells in L5 (\%): $\mathrm{PB}_{15}: 0.34$ $\pm 0.28 ; \mathrm{PB}_{12}: 22.46 \pm 3.45$. Cells in $\mathrm{L} 6(\%): \mathrm{PB}_{15}: 0.14 \pm 0.14 ; \mathrm{PB}_{12}: 28.26 \pm 2.87 . \mathrm{AP}_{15 \rightarrow 15}$ and $\mathrm{AP}_{12 \rightarrow 12}$ plots are reused from Fig. 1. A two-way ANOVA with post-hoc Tukey test was used.

Figure S5b: The layer position for all cells depicted in Figure 1 was plotted $(\mathrm{N}=$ recipient litter). In cortical areas with no anatomically distinguishable L4, the lowest third of L2/3 was arbitrarily considered as L4. Cells in L2/3 (\%): $\mathrm{AP}_{15 \rightarrow 15}: 85.79 \pm 2.58$; $\mathrm{AP}_{12 \rightarrow 12}: 41.32 \pm 5.71 ; \mathrm{AP}_{15 \rightarrow 12}: 43.16 \pm$ 3.63. Cells in L4 (\%): $\mathrm{AP}_{15 \rightarrow 15}: 10.78 \pm 2.24 ; \mathrm{AP}_{12 \rightarrow 12}: 8.28 \pm 3.18$; $\mathrm{AP}_{15 \rightarrow 12}: 5.75 \pm 1.54$. Cells in L5 (\%): $\mathrm{AP}_{15 \rightarrow 15}: 5.6 \pm 2.16 ; \mathrm{AP}_{12 \rightarrow 12}: 25.61 \pm 3.99 ; \mathrm{AP}_{15 \rightarrow 12}: 33.09 \pm 2.15$. Cells in L6 (\%): $\mathrm{AP}_{15 \rightarrow 15}$ : $1.01 \pm 0.79 ; \mathrm{AP}_{12 \rightarrow 12}: 24.79 \pm 4.07 ; \mathrm{AP}_{15 \rightarrow 12}: 18 \pm 3.90$. A two-way ANOVA with post-hoc Tukey test was used.

Figure S6a-c: A subset of $\mathrm{GFP}^{+}$neurons depicted in Fig. S4 was analyzed for molecular marker expression. Epor ${ }_{\mathrm{PB} 15}: 380$ cells from 5 pups $(=\mathrm{N})$ were stained for CUX1 $\left(\% \mathrm{CUX1}^{+}: 94.96 \pm 2.13\right)$; 380 cells from 5 pups were stained for CTIP2 (\% CTIP2 $\left.2^{+}: 0 \pm 0\right)$; 304 cells from 3 pups were stained for TBR1 (\% TBR $\left.1^{+}: 1.89 \pm 1.51\right)$. EporPB12: 843 cells from 3 pups were stained for CUX1 (\% $\left.\mathrm{CUX1}^{+}: 52.56 \pm 6.1\right) ; 961$ cells from 3 pups were stained for CTIP2 (\% CTIP2 $\left.{ }^{+}: 31.36 \pm 1.29\right) ; 891$ cells from 3 pups were stained for TBR1 ( $\%$ TBR $\left.1^{+}: 31.36 \pm 1.29\right)$. The normalized radial position of labeled and non-labeled $\mathrm{GFP}^{+}$neurons was plotted for $50-100$ randomly selected cells for each 
condition and the total percentage of all cells expressing the respective marker were plotted. $\mathrm{AP}_{15 \rightarrow 15}$ and $\mathrm{AP}_{12 \rightarrow 12}$ plots and images showing expression of CUX1, CTIP2 and TBR1 within the neocortical layers are copied from Fig 2. A one-way ANOVA with post-hoc Tukey test was used.

Figure S6d: The fraction of $\mathrm{EdU}^{+}$neurons at $\mathrm{P} 7$ from 7 donor litters across all conditions is shown.

Figure S9a: Three sections from different rostro-caudal levels from 3 pups $(=\mathrm{N})$ were used to quantify the number of $\mathrm{FT}^{+} \mathrm{TBR}^{+} \mathrm{Ki}^{+} 7^{+}$cells 10 hours after FT labeling at E15.5 $\left(\% \mathrm{FT}^{+} \mathrm{TBR}^{+}\right.$ Ki67 $: 70.99 \pm 2.81)$.

Figure S9b: The number of cells per integration site (oligoclone size) was analyzed pooling all cells from previous experiments. $\mathrm{AP}_{15 \rightarrow 12}: 8.11 \pm 1.02 ; \mathrm{IP}_{15 \rightarrow 12}: 3.77 \pm 0.89$.

Figure S9d: A subset of EdU ${ }^{+}$cells depicted in Fig. 4d-f was analyzed for molecular marker expression. The normalized radial position of labeled and non-labeled cells and the total percentage of cells expressing the respective marker were plotted. A total of 15 cells from 2 independent experiments were stained for CUX1 $\left(\% \mathrm{CUX}^{+}: 93.75 \pm 6.25\right) ; 63$ cells from 3 independent experiments were stained for CTIP2 $\left(\% \mathrm{CTIP}^{+}: 0.83 \pm 0.83\right)$. Images showing expression of CUX1 and CTIP2 within the neocortical layers are the same as in Fig. 2.

Figure S9e: The radial position of all $\mathrm{RFP}^{+}$EdU neurons from subset of experiments shown in Fig. 4d-f (22 cells from 2 independent experiments) was measured and normalized to the cortical thickness.

\section{Electrophysiology and collection of cells for single-cell RNA sequencing}

Three hundred $\mu \mathrm{m}$ thick coronal slices were prepared 24 hours after transplantation or FT labeling. Slices were kept for at least 30 minutes in artificial cerebrospinal fluid (aCSF) at $33^{\circ} \mathrm{C}(125 \mathrm{mM}$ $\mathrm{NaCl}, 2.5 \mathrm{mM} \mathrm{KCl}, 1 \mathrm{mM} \mathrm{MgCl}, 2.5 \mathrm{mM} \mathrm{CaCl}_{2}, 1.25 \mathrm{mM} \mathrm{NaH}_{2} \mathrm{PO}_{4}, 26 \mathrm{mM} \mathrm{NaHCO}_{3}$ and $11 \mathrm{mM}$ glucose, saturated with $95 \% \mathrm{O}_{2}$ and $5 \% \mathrm{CO}_{2}$ ) before recording. The slices were then transferred in the recording chamber, submerged and continuously perfused with aCSF. The internal solution used for the experiments contained $140 \mathrm{mM}$ potassium methansulfonate, $2 \mathrm{mM} \mathrm{MgCl}_{2}, 4 \mathrm{mM} \mathrm{NaCl} 0.2 \mathrm{mM}$ EGTA, $10 \mathrm{mM}$ HEPES, $3 \mathrm{mM} \mathrm{Na} 2 \mathrm{ATP}, 0.33 \mathrm{mM}$ GTP and $5 \mathrm{mM}$ creatine phosphate $(\mathrm{pH} 7.2,295$ mOsm).

For resting membrane potential recordings, immediately after the whole-cell configuration, resting membrane potential was measured in current-clamp mode. Membrane potential was monitored every 10 seconds and averaged for 6 consecutive acquisitions, within the first 2 minutes after the whole-cell configuration establishment. $\mathrm{V}_{\mathrm{m}}$ remained stable within conditions and was significantly different across conditions throughout the duration of the recording, indicating that $\mathrm{V}_{\mathrm{m}}$ recordings are not influenced by cytoplasmic dilution with the patch pipette solution. Recordings were amplified (Multiclamp 700, Axon Instruments), filtered at $5 \mathrm{kHz}$ and digitalized at $20 \mathrm{kHz}$ (National Instrument Board PCI-MIO-16E4, IGOR WaveMetrics), and stored on a personal computer for further analyses (IGOR PRO WaveMetrics). Values are represented as mean \pm SEM.

For collection of cells for single-cell RNA sequencing, FT-labeled non-transplanted or RFP ${ }^{+}$ transplanted progenitors located in the ventricular zone were patched with a patch pipette containing 1 $\mu \mathrm{l}$ of internal solution supplemented with $1 \mathrm{U} / \mathrm{mL}$ of RNase inhibitor (Takara). To facilitate the aspiration of the cell, low pipette resistance was used (4-3 M $\Omega$ ). Once in whole cell configuration, a slit depression was applied to the pipette to aspirate the intracellular content. The complete aspiration of the cell was observed under high magnification (Nikon Eclipse FN1, 60x lens) as retraction of the cytoplasm and total aspiration of the nucleus. The patch pipette was then slowly retracted and the pipette tip containing the cell content was broken into a PCR RNase free Eppendorf containing $8 \mu 1$ of lysis buffer and stored at $-80^{\circ} \mathrm{C}$ until further processing. 


\section{Single-cell RNA sequencing}

cDNA synthesis and preamplification were performed using the SMART-Seq v4 3' DE Kit following the manufacturer's instructions (Takara). Single cell RNA-sequencing libraries of the cDNA were prepared using the Nextera XT DNA library prep kit (Illumina). Libraries were multiplexed and sequenced according to the manufacturer's recommendations with paired-end reads using the HiSeq4000 plat-form (Illumina) with an expected depth of $1 \mathrm{M}$ reads per single cell, and a final mapping read length of $50 \mathrm{bp}$. Each pool contained cells from different collection days and conditions. All single cell RNA capture and sequencing experiments were performed within the Genomics Core Facility of the University of Geneva. The sequenced reads were aligned to the mouse genome (GRCm38) using STAR aligner. The number of reads per transcript was calculated with the open-source HTSeq Python library. All analyses were computed on the Vital-It cluster administered by the Swiss Institute of Bioinformatics.

\section{Single-cell RNA sequencing analysis}

Cell filtering: A total of 91 cells ( $\mathrm{AP}_{12}: 31$ cells, $\mathrm{AP}_{15}: 31$ cells, $\mathrm{AP}_{15 \rightarrow 12}: 29$ cells) were sequenced. Cells expressing $<2000$ genes or $>12 \%$ of mitochondrial genes were excluded ( $\mathrm{N}=26$ cells). A total of 65 cells were analyzed ( $\mathrm{AP}_{12}: 20$ cells, $\mathrm{AP}_{15}: 26$ cells, $\mathrm{AP}_{15 \rightarrow 12}: 29$ cells: 19 cells). Gene expression was normalized to reads per million (rpm) and log transformed. Cell cycle effect was corrected for using the ccRemover package. We used the Support Vector Machine (SVM) method implemented in the bmrm $\mathrm{R}$ package to classify the age of progenitors with genes showing minimal expression $(10,407)$ as previously described (Teo et al., 2010). The model was trained with a subset of $\mathrm{AP}_{12}$ and $\mathrm{AP}_{15}$ progenitors and the 30 most weighted genes were used for leave-one-out cross validation of additional $\mathrm{AP}_{12}$ and $\mathrm{AP}_{15}$ progenitors and prediction of $\mathrm{AP}_{15 \rightarrow 12}$ cells. The same method was applied to build a model to classify $\mathrm{AP}_{15}$ and $\mathrm{AP}_{15 \rightarrow 12}$, selecting for 100 most weighted genes. 
bioRxiv preprint doi: https://doi.org/10.1101/478891; this version posted November 27, 2018. The copyright holder for this preprint (which was not certified by peer review) is the author/funder, who has granted bioRxiv a license to display the preprint in perpetuity. It is made available under aCC-BY-NC-ND 4.0 International license.
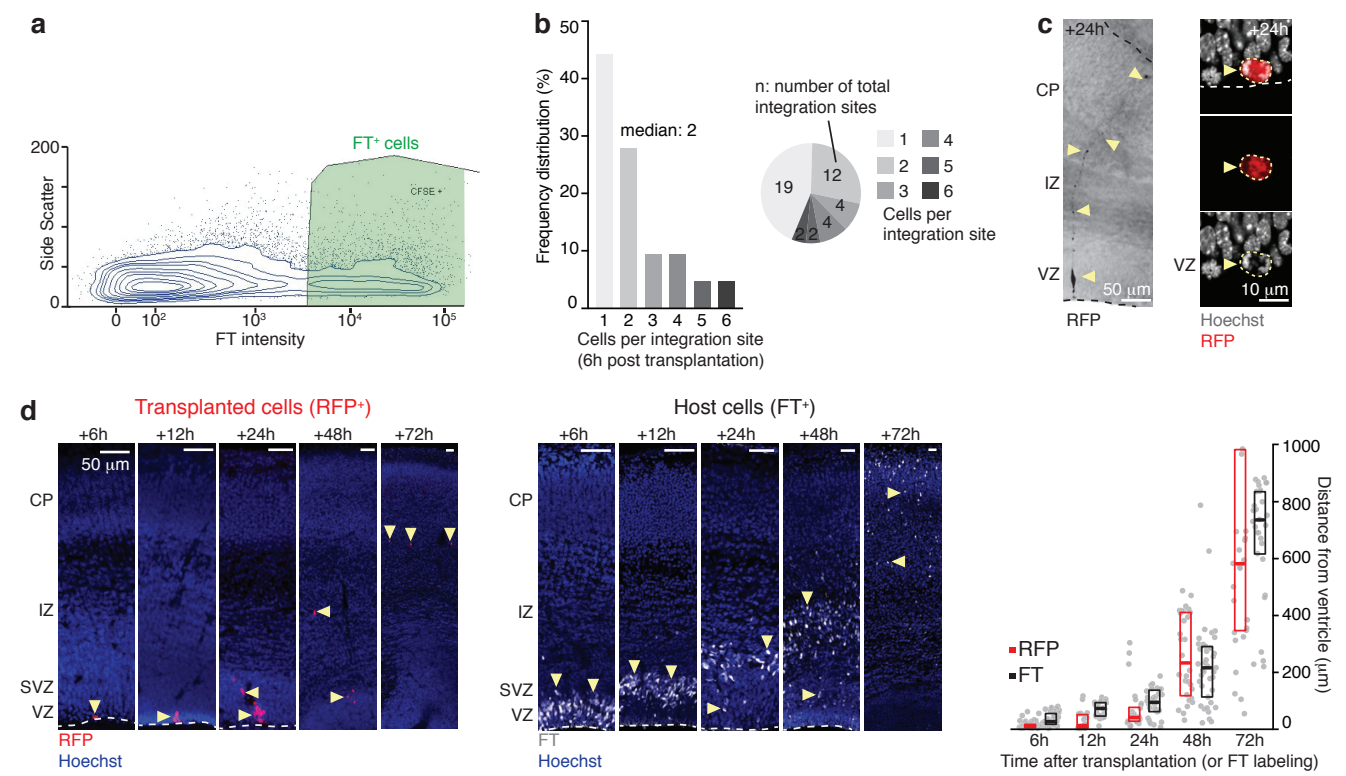

Figure S1: Donor APs rapidly integrate the VZ and behave normally. a, FAC-sorting of $\mathrm{FT}^{+}$cells 1 hour after labeling. b. Donor APs integrate the host VZ at discrete sites. Only a few APs (median $=2$ ) are present at each site, such that daughter neurons found at single integration sites at P7 are likely born from a small number of initial APs ("oligoclonal" analysis, see Fig.1g and Fig. 4b,f). c, Left: Photomicrograph of a transplanted AP showing a radial glia morphology. Right: Juxtaventricular mitosis in a transplanted AP. d, The progeny of transplanted APs progressively migrate towards the cortical plate. The time course of this migration is similar to that of the host cells, as assessed by comparison with the migration of FT-labelled endogenous cells. CP: cortical plate; FT: FlashTag; IZ: intermediate zone; SVZ: subventricular zone; VZ: ventricular zone. 
bioRxiv preprint doi: https://doi.org/10.1101/478891; this version posted November 27, 2018. The copyright holder for this preprint (which was not certified by peer review) is the author/funder, who has granted bioRxiv a license to display the preprint in perpetuity. It is made available under aCC-BY-NC-ND 4.0 International license.
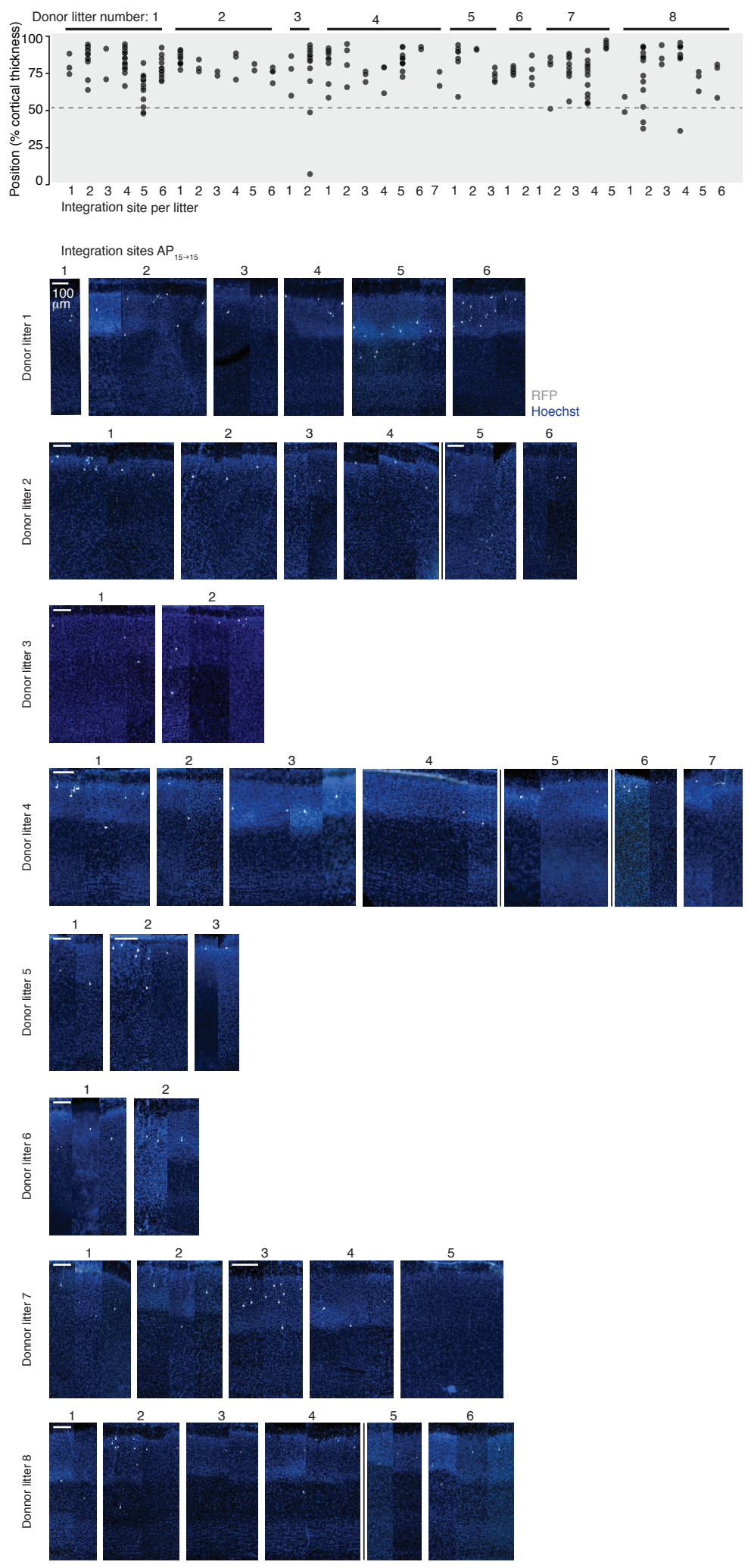

Figure S2: Analysis of single integration sites: $\mathbf{A P}_{15 \rightarrow 15^{*}}$ Isochronically transplanted E15.5 APs $\left(\mathrm{AP}_{15 \rightarrow 15}\right)$ essentially generate SL neurons. Photomicrographs: within each donor litter, illustrations are clustered by integration site. When applicable, a vertical black line delineates distinct host pups within a given litter. 
bioRxiv preprint doi: https://doi.org/10.1101/478891; this version posted November 27, 2018. The copyright holder for this preprint (which was not certified by peer review) is the author/funder, who has granted bioRxiv a license to display the preprint in perpetuity. It is made available under aCC-BY-NC-ND 4.0 International license.
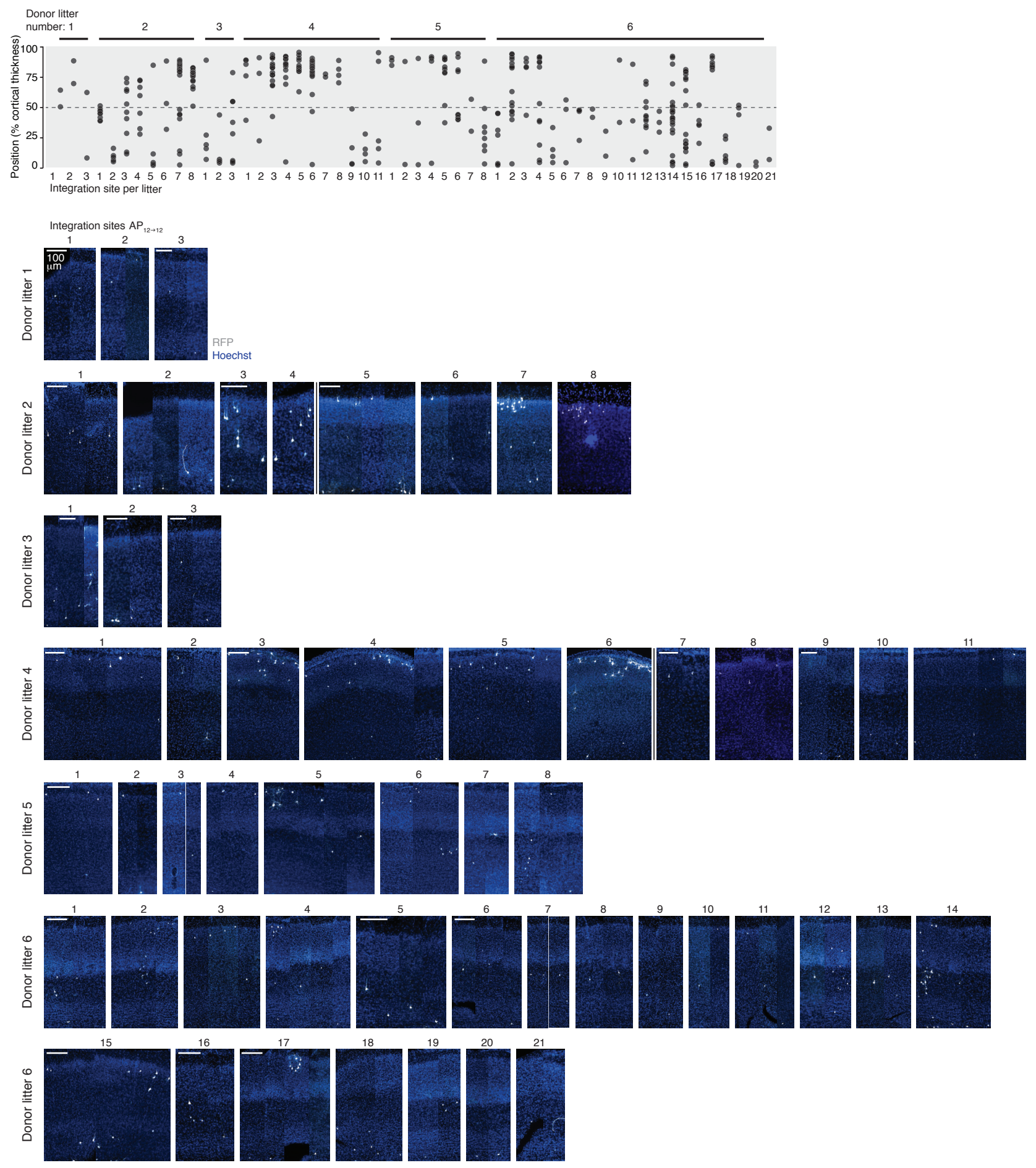

Figure S3: Analysis of single integration sites: $\mathbf{A P}_{12 \rightarrow 12^{*}}$ Isochronically transplanted E12.5 APs ( $\left.\mathrm{AP}_{12 \rightarrow 12}\right)$ generate DL and SL neurons. Photomicrographs: within each donor litter, illustrations are clustered by integration site. When applicable, a vertical black line delineates distinct host pups within a given litter. 
bioRxiv preprint doi: https://doi.org/10.1101/478891; this version posted November 27, 2018. The copyright holder for this preprint (which was not certified by peer review) is the author/funder, who has granted bioRxiv a license to display the preprint in perpetuity. It is made available under aCC-BY-NC-ND 4.0 International license.
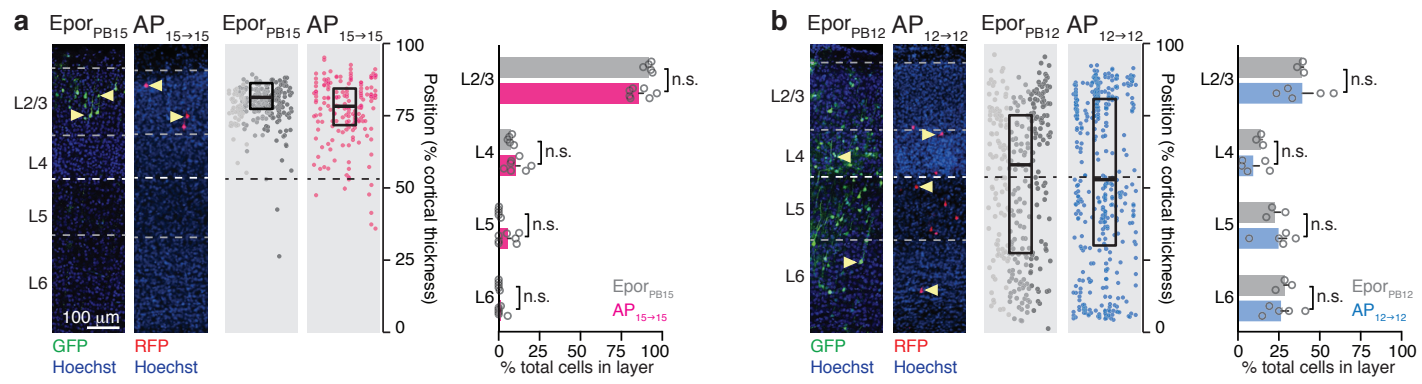

Figure S4 : The transplantation procedure does not affect the neurogenic competence of APs. a, The laminar distribution of daughter neurons in the $\mathrm{AP}_{15 \rightarrow 15}$ condition is replicated by in utero electroporation of a piggyBac-transposon construct at E15.5, in the absence of transplantation. $\mathbf{b}$, The laminar distribution of daughter neurons in the $\mathrm{AP}_{12 \rightarrow 12}$ condition is replicated by in utero electroporation of a piggyBac-transposon construct at E12.5. a-b: Two-way ANOVA with post-hoc Tukey test. 
bioRxiv preprint doi: https://doi.org/10.1101/478891; this version posted November 27, 2018. The copyright holder for this preprint (which was not certified by peer review) is the author/funder, who has granted bioRxiv a license to display the preprint in perpetuity. It is made available under aCC-BY-NC-ND 4.0 International license.
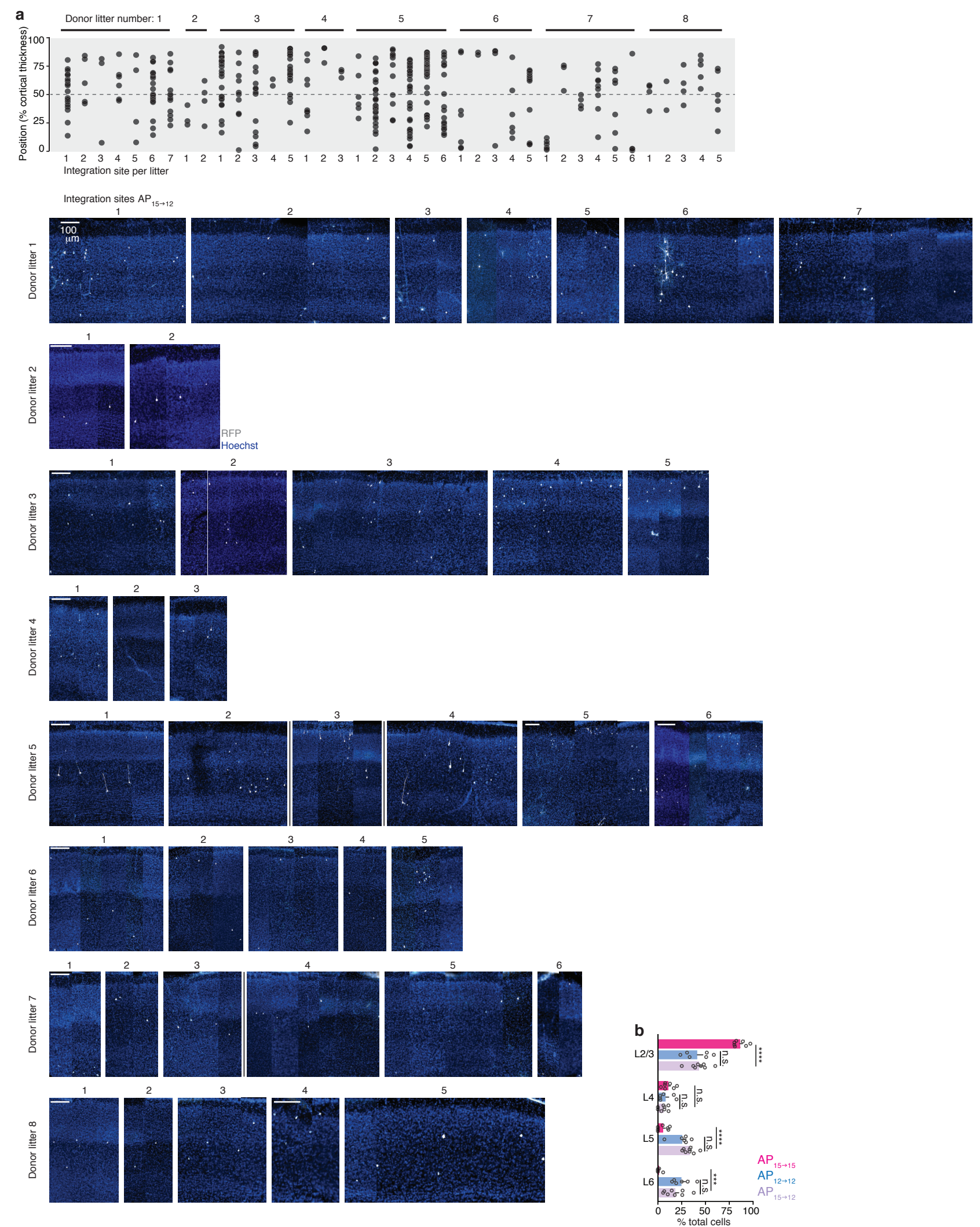

Figure S5 : Analysis of single integration sites: AP ${ }_{15 \rightarrow 12^{*}}$ a, E15.5 APs transplanted into an E12.5 host $\left(\mathrm{AP}_{15 \rightarrow 12}\right)$ generate $\mathrm{DL}$ and $\mathrm{SL}$ neurons. Photomicrographs: within each donor litter, illustrations are clustered by integration site. When applicable, a vertical black line delineates distinct host pups within a given litter. $\mathbf{b}$, Laminar distribution of daughter neurons across conditions. $\mathrm{AP}_{15 \rightarrow 15}$ and $\mathrm{AP}_{12 \rightarrow 12}$ distribution plots are copied from Fig. S4 to allow for direct comparison across conditions. Two-way ANOVA with post-hoc Tukey test. ***: $\mathrm{P}$ $<0.001,{ }^{* * *}: \mathrm{P}<0.0001$. 
bioRxiv preprint doi: https://doi.org/10.1101/478891; this version posted November 27, 2018. The copyright holder for this preprint (which was not certified by peer review) is the author/funder, who has granted bioRxiv a license to display the preprint in perpetuity. It is made available under aCC-BY-NC-ND 4.0 International license.
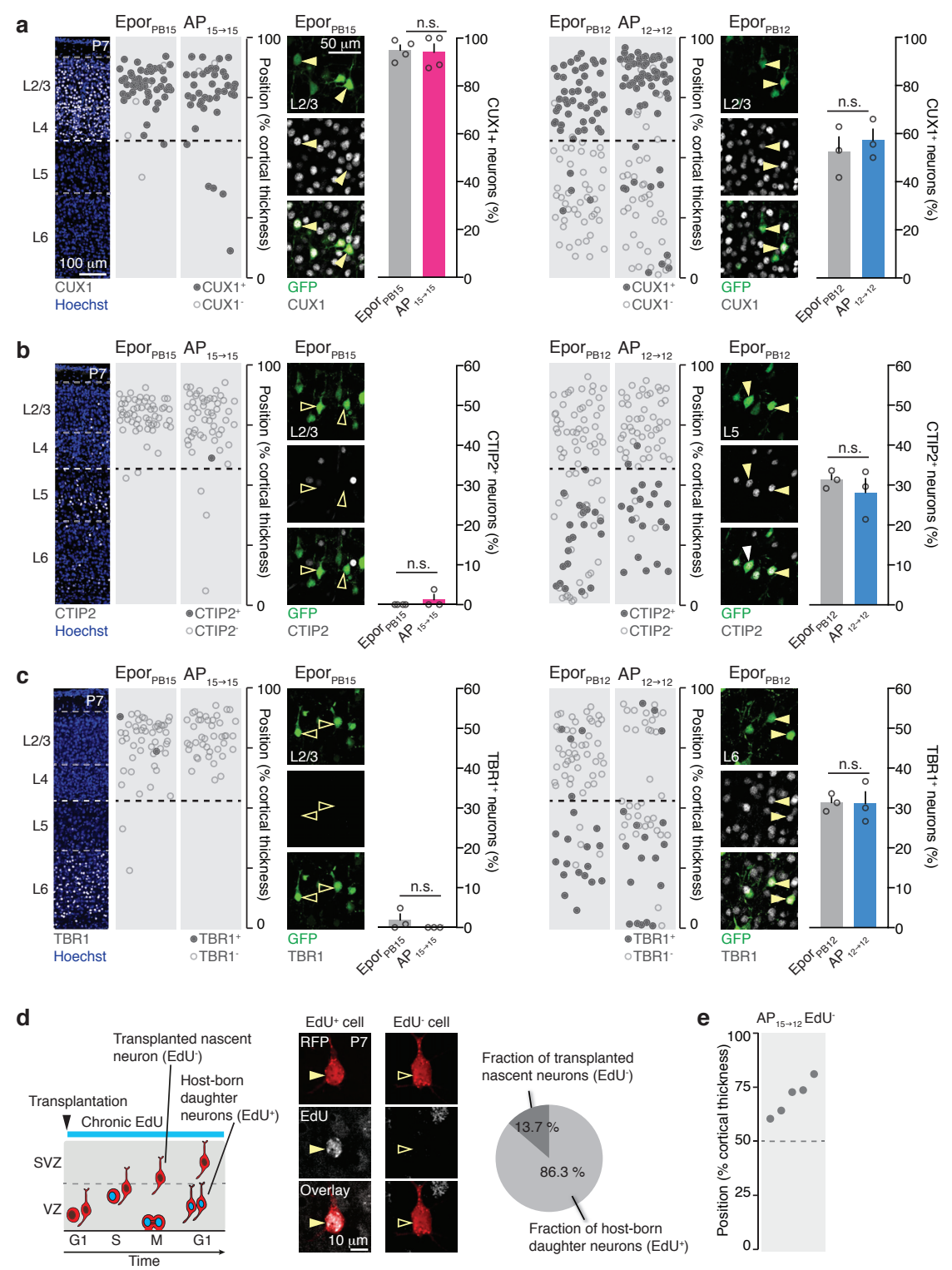

Figure S6 : Molecular markers following piggybac electroporation; approach to identify transplanted nascent neurons. a, SL neurons in the isochronic transplantation and piggybac (PB) electroporation conditions both express CUX1. b, Daughter neurons of $\mathrm{PB}_{15}$ and $\mathrm{AP}_{15 \rightarrow 15}$ do not express CTIP2. In $\mathrm{PB}_{12}$ and $A \mathrm{P}_{12 \rightarrow 12}$ conditions, CTIP2+ daughter neurons are located in DL. c, Daughter neurons of $\mathrm{PB}_{15}$ and $\mathrm{AP}_{15 \rightarrow 15}$ do not express TBR1. In $\mathrm{PB}_{12}$ and $\mathrm{AP}_{12 \rightarrow 12}$ conditions, TBR1+ daughter neurons are located in DL. a-c: One-way ANOVA with post-hoc Tukey test. Photomicrographs showing pattern of expression of CUX1, CTIP2 and TBR1 are copied from Figure 2. d, Left: Schematic representation of the chronic EdU labeling approach used to distinguish between nascent donor neurons and neurons born in the host. Center: photomicrograph showing examples of an $\mathrm{EdU}^{+}$and an EdU- donor neuron. Right: Quantification of the fraction of EdU- labeled neurons at P7 (i.e. transplanted cells which never underwent division in the host). e, Heterochronically transplanted E15.5 nascent neurons migrate to the superficial layers, as they would have done in their original host. M: mitosis ; S: S-phase; SVZ: subventricular zone; VZ: ventricular zone. 
bioRxiv preprint doi: https://doi.org/10.1101/478891; this version posted November 27, 2018. The copyright holder for this preprint (which was not certified by peer review) is the author/funder, who has granted bioRxiv a license to display the preprint in perpetuity. It is made available under aCC-BY-NC-ND 4.0 International license.

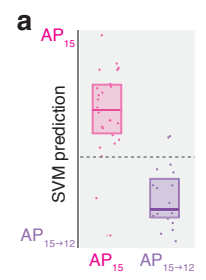

b $\mathrm{AP}_{15}$ enriched transcripts $\quad \mathrm{AP}_{12} \quad \mathrm{AP}_{15}$

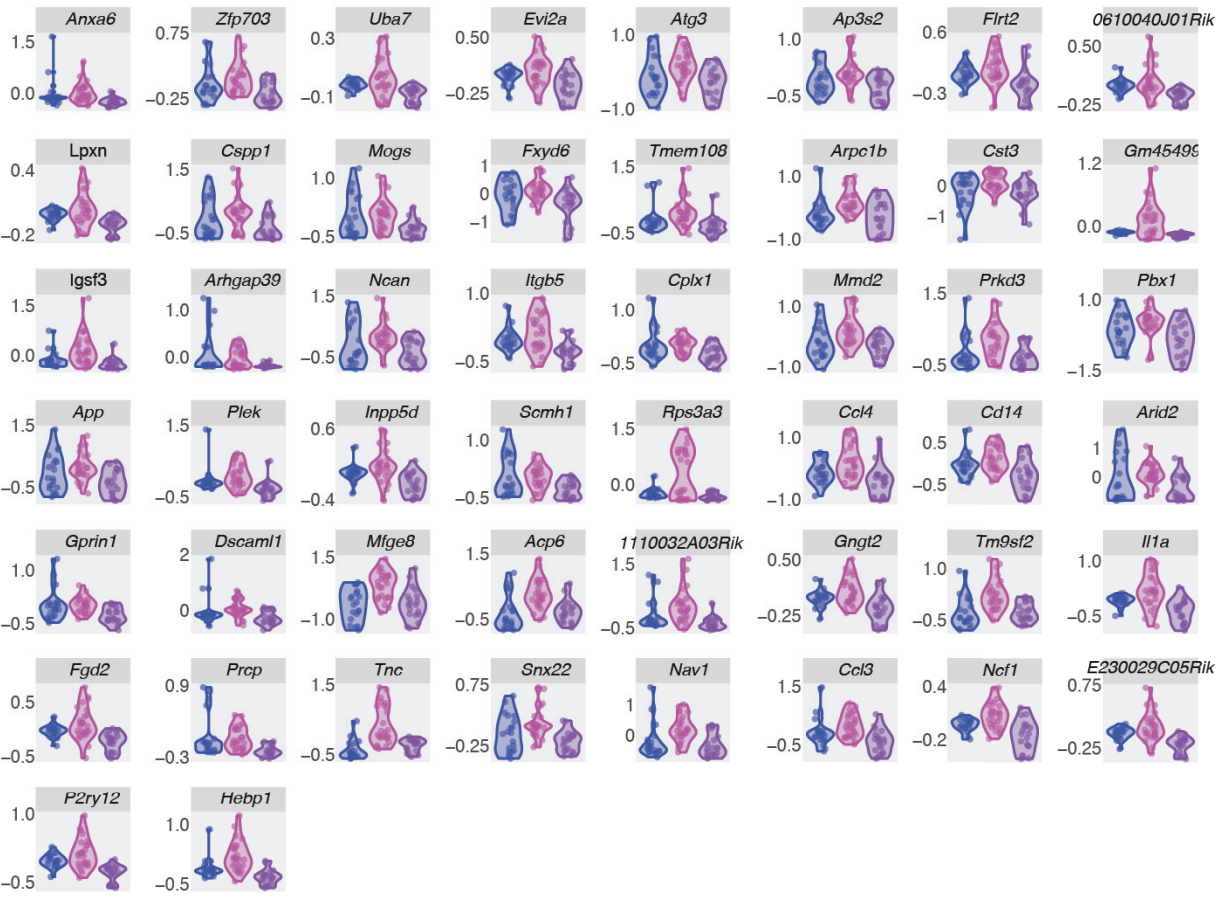

c $\quad \mathrm{AP}_{15 \rightarrow 12}$ enriched transcripts
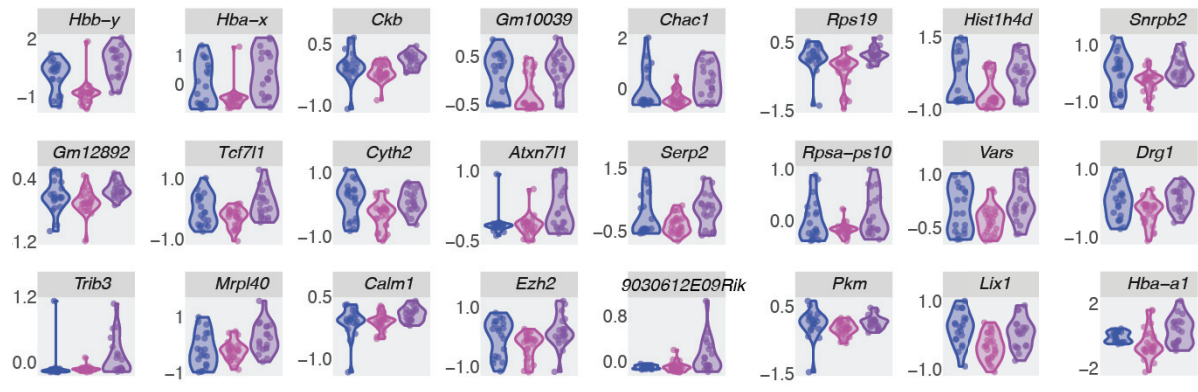

srrm1
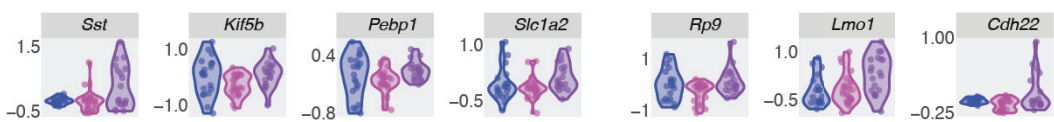

10 Nktr 1.0 Crabp2
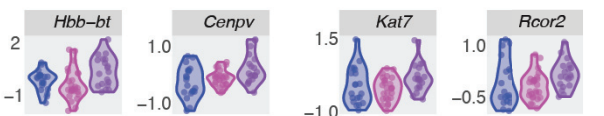

D2Bwg1423e
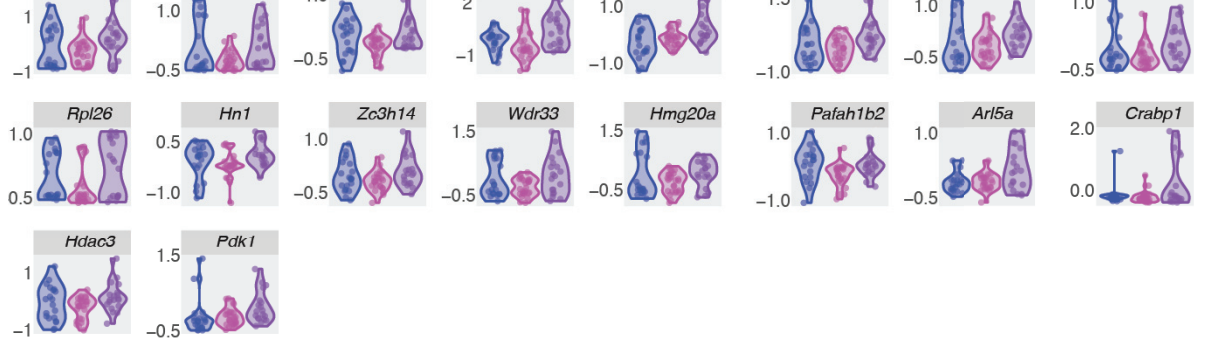

Figure S7 : Repression of $\mathrm{AP}_{15}$-type transcriptional programs and re-induction of $\mathrm{AP}_{12}$-type transcriptional programs in $\mathrm{AP}_{15 \rightarrow 12^{*}}$ a, SVM classification of $A P_{15 \rightarrow 15}$ and $A P_{15 \rightarrow 12} \cdot \mathbf{b}$, Expression of the $A P_{15}$ transcripts used in the model. c, Expression of the $\mathrm{AP}_{15 \rightarrow 12}$ transcripts used in the model. 
bioRxiv preprint doi: https://doi.org/10.1101/478891; this version posted November 27, 2018. The copyright holder for this preprint (which was not certified by peer review) is the author/funder, who has granted bioRxiv a license to display the preprint in perpetuity. It is made available under aCC-BY-NC-ND 4.0 International license.
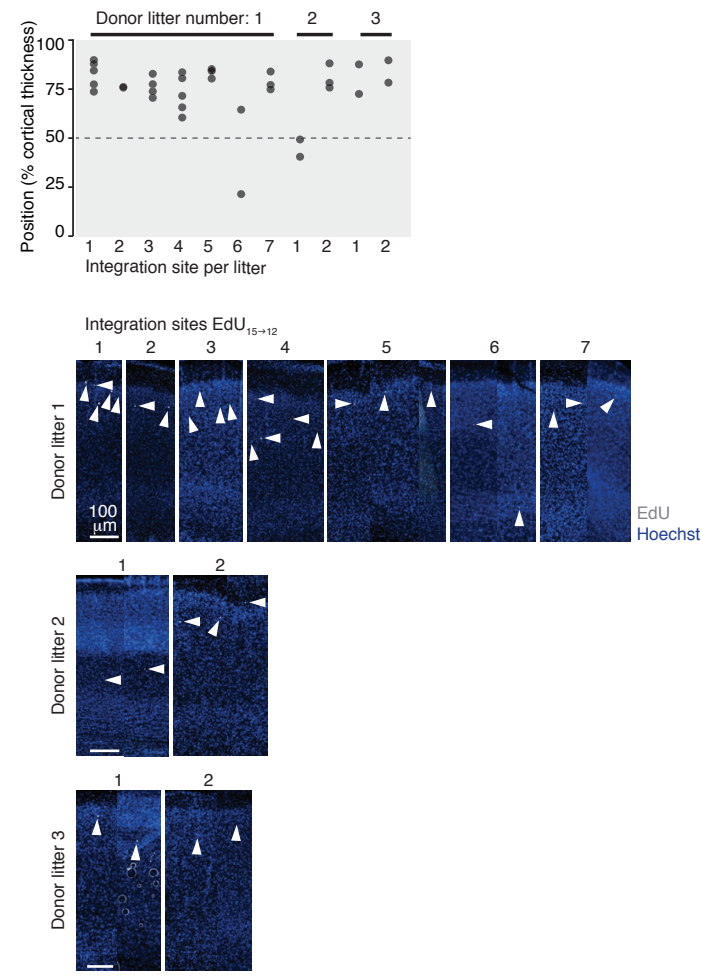

Figure S8 : Oligoclonal analysis of single integration sites: EdU ${ }_{15 \rightarrow 12^{*}}$ Heterochronically transplanted EdU-labeled progenitors $\left(\mathrm{EdU}_{15 \rightarrow 12}\right)$ essentially generate $\mathrm{SL}$ neurons. Photomicrographs: within each donor litter, illustrations are clustered by integration site. 
bioRxiv preprint doi: https://doi.org/10.1101/478891; this version posted November 27, 2018. The copyright holder for this preprint (which was not certified by peer review) is the author/funder, who has granted bioRxiv a license to display the preprint in perpetuity. It is made available under aCC-BY-NC-ND 4.0 International license.
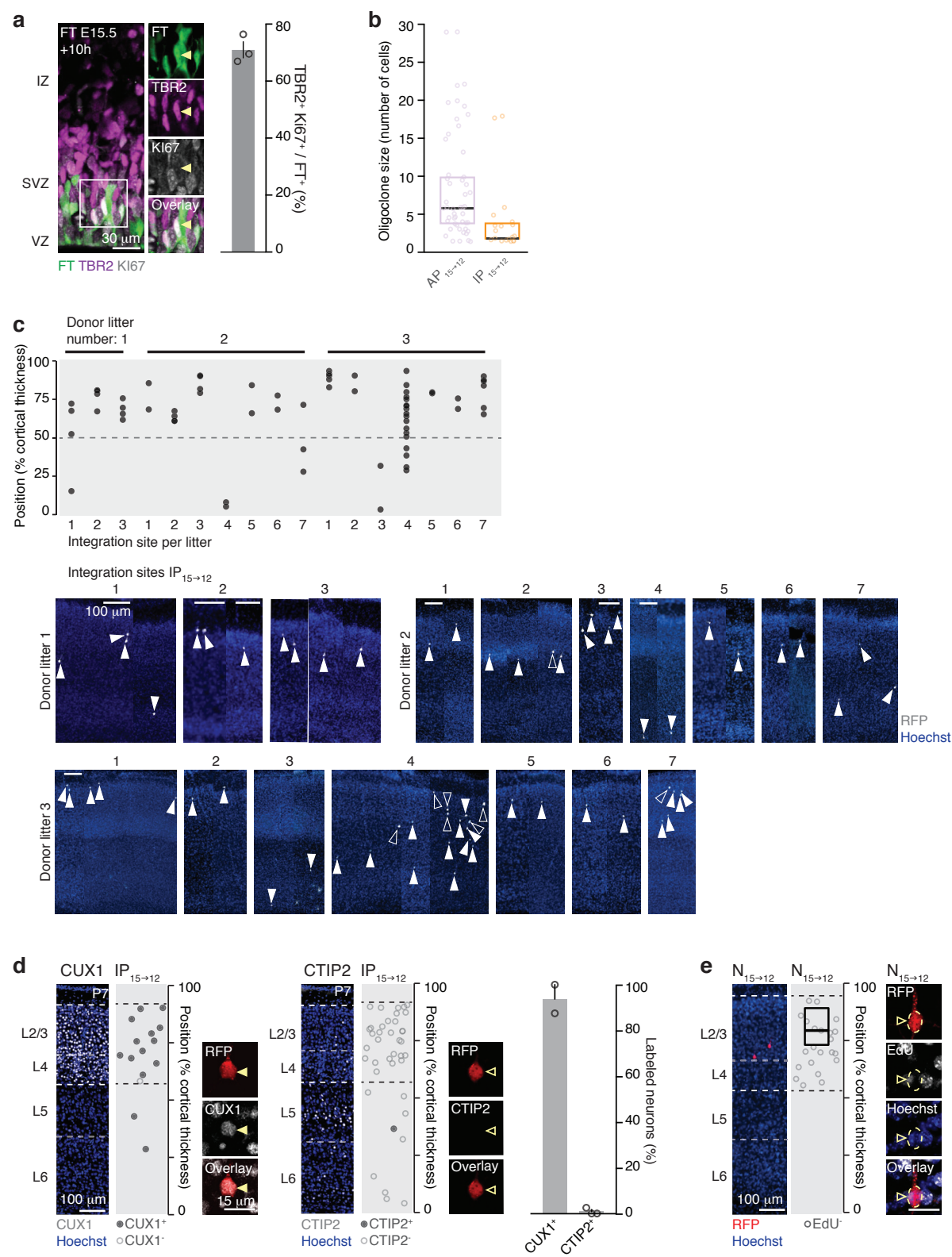

Figure S9 : Heterochronically transplanted IPs $\left(\mathrm{IP}_{15 \rightarrow 12}\right)$ generate SL neurons. a, Ten hours after FT labeling, most cells have differentiated into IPs (i.e. $\mathrm{KI} 167^{+}$TBR2 ${ }^{+}$cells). $\mathbf{b}$, Number of cells per integration site. Each point represents one oligoclone. c, IP $\mathrm{I}_{15 \rightarrow 12}$ essentially give rise to $\mathrm{SL}$ neurons. Photomicrographs: within each donor litter, illustrations are clustered by integration site. Only EdU+ neurons (filled arrowheads) were included in this analysis. $\mathbf{d}, \mathrm{IP}_{15 \rightarrow 12}$ daughter neurons express CUX1 but not CTIP2. e, Neurons that were post-mitotic at the time of transplantation migrate to SL. FT: FlashTag; IZ: intermediate zone; SVZ: subventricular zone; TBR2: IP marker; VZ: ventricular zone. 